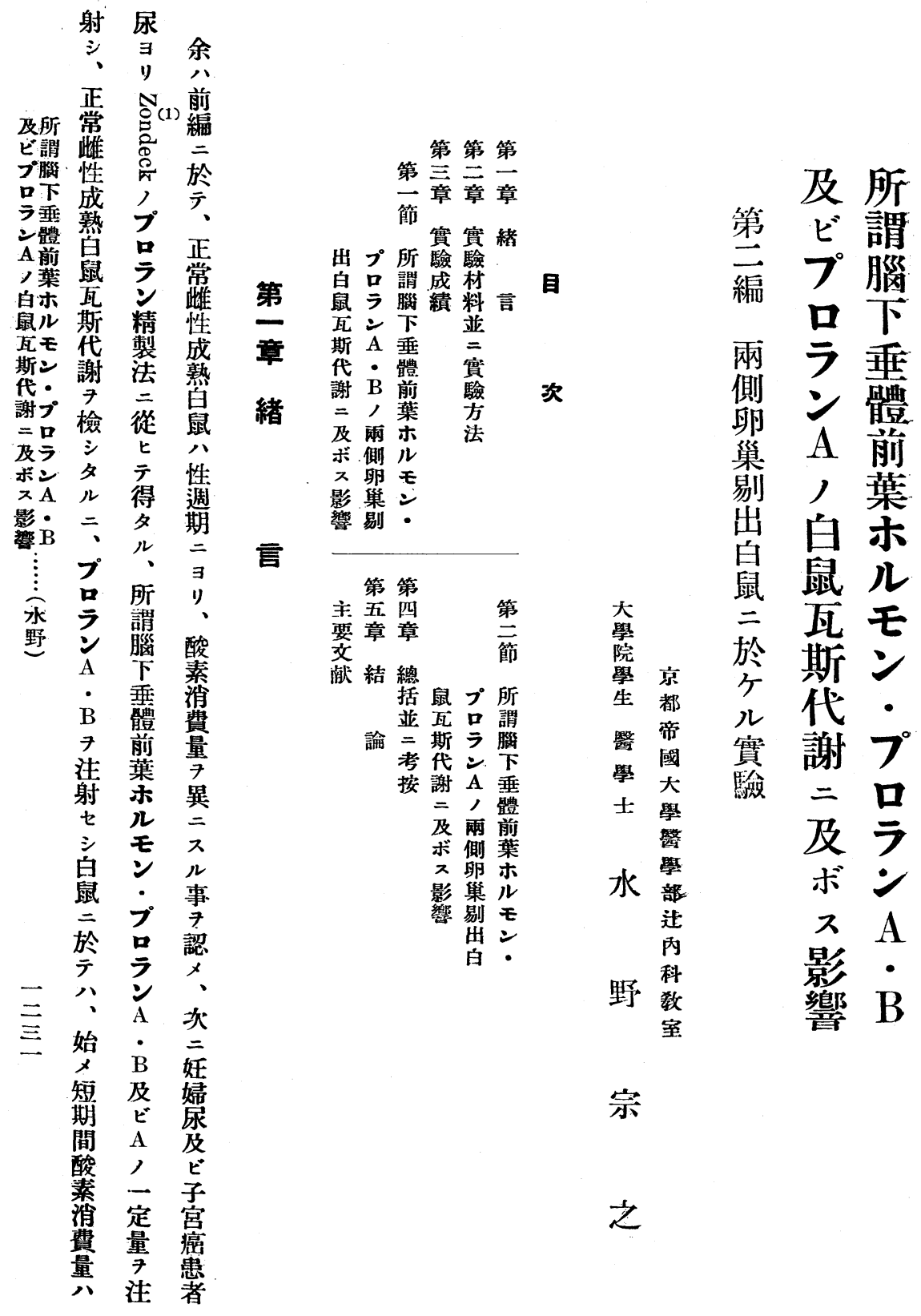




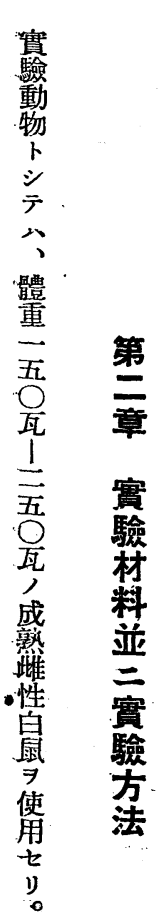

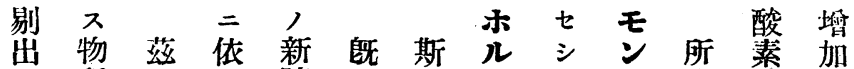

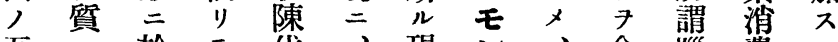

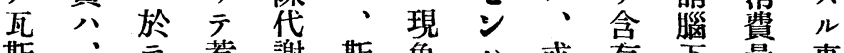
斯・ 惹謝斯象八或有下量事及所 代 卯余起 謝巢八七、尛生次黄儿體進レプ腦 二 $、 5$ 管如體的體事性 シ 5 口下 及介卵 $v=キ$ 新二方出、、ラ垂 ボシ巢タプ關陳雌發論儿呼爾方體 不剔ル口係代性生二モ吸後㮍 影三出、ラ $>$ 謝生 7 シ ン 係酸白ホ 響次白卵 $ン$ 存二殖促テナナ數素鼠ル 子的鼠巢中入影器 モ二ニノノル 響云、之ブ卞費斯ン

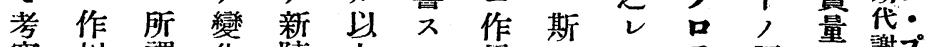
究用謂化陳上心角》心 七 惱三帒:

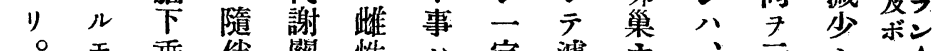

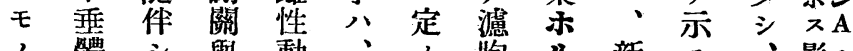
ノ體 シ 興動、光胞儿新 ス ・影・ ナ性 テ物 物 卵變 ホ モ陳事呼響B 小 二貿二巢化ルン代 7 吸

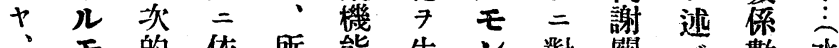

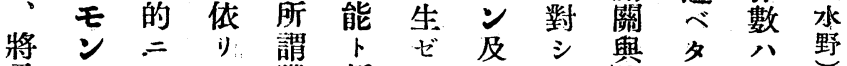

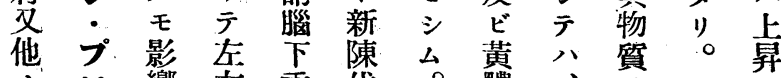

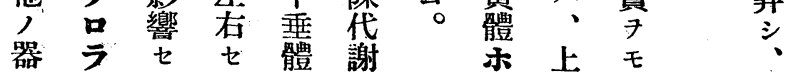

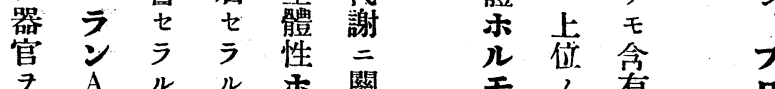
尹、A А ホ關 モ, 有 介・ベ、ルン ン ホ ス

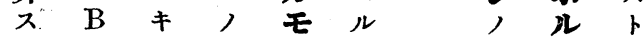
ル及

モビ・ナナ數 ノ. 蓋ラルノ

ナ・ シ ズプ 業

ル注理、績

$ヤ$ 射, プラ’

究 シ. 當

究...然 三 證

メ新ナソ 投

ン陳リ中, 興虑

シ 謝 性 シ 處

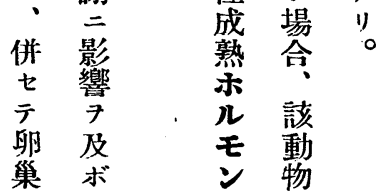

分 モ 雖

泌ン无

促 $卜 \therefore$

進 シ 濾

七 テ胞

亏 卵成

2 巢 熟

、 ホ

分働 几

汼キ、モ

促、

進 今 黃

只

ラ濾 體

々.胞發

A

注

射

ル成 ホ

七

白 三

$=$

於

テ

八

此

兩 熟 几

反 

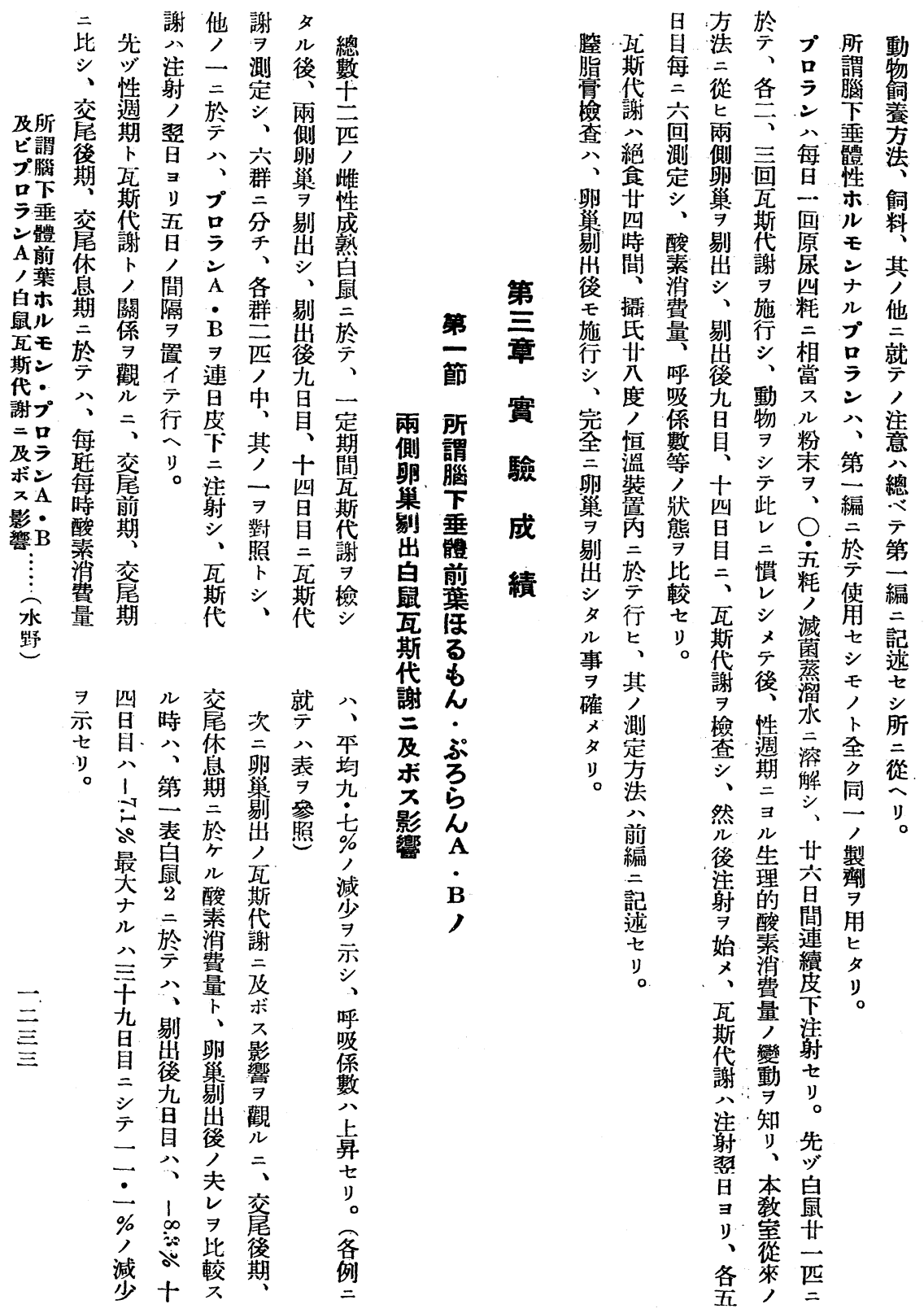


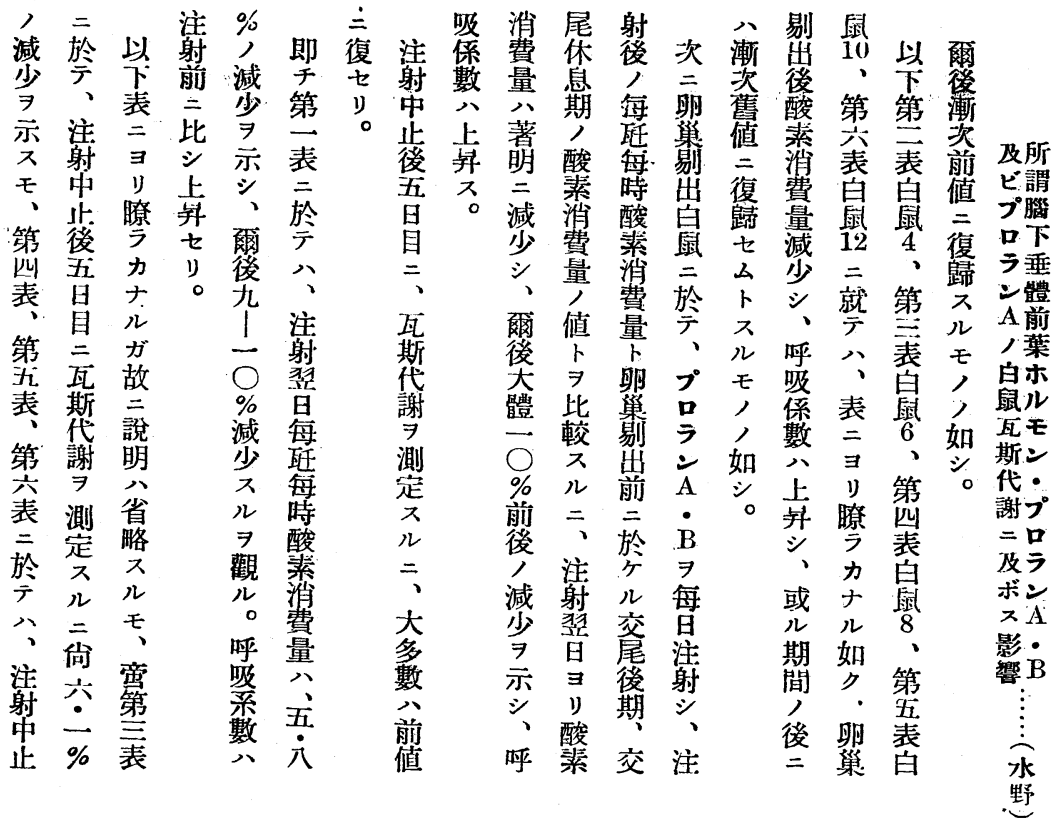

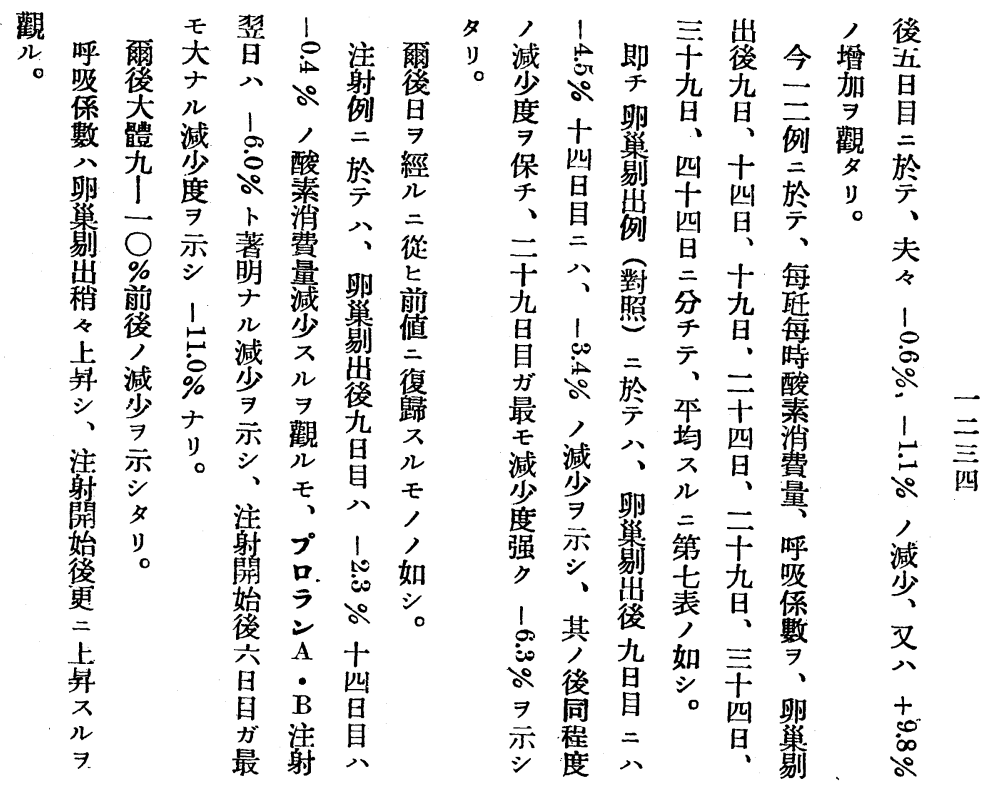




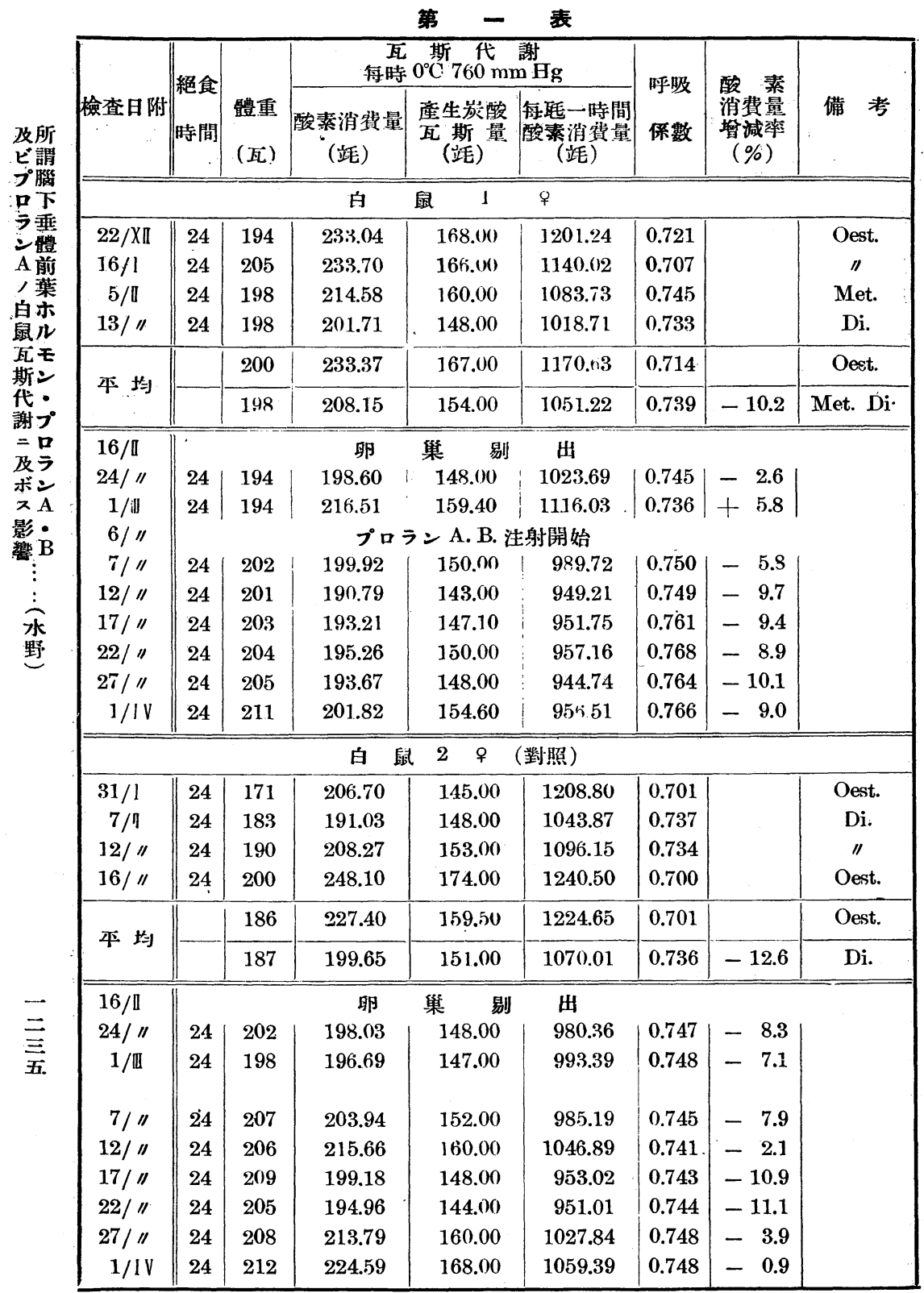

借 考：交尾前期八 Pro. 交尾期八Oest. 交尾後期八 Met. 


\begin{tabular}{|c|c|c|c|c|c|c|c|c|}
\hline \multirow[b]{2}{*}{ 檢查日附 } & \multirow{2}{*}{$\mid \begin{array}{l}\text { 絶食 } \\
\text { 時間 }\end{array}$} & \multirow[b]{2}{*}{$\begin{array}{l}\text { 體重 } \\
\text { (宜) }\end{array}$} & \multicolumn{3}{|c|}{$\begin{array}{c}\text { 㼛 斯 代 謝 } \\
\text { 每時 } 0^{\circ} 760 \mathrm{~mm} \mathrm{Hg}\end{array}$} & \multirow[b]{2}{*}{$\begin{array}{l}\text { 呼吸 } \\
\text { 係數 }\end{array}$} & \multirow[b]{2}{*}{$\begin{array}{c}\text { 酸素 } \\
\text { 消費量 } \\
\text { 㴰減玄 } \\
(\%)\end{array}$} & \multirow[b]{2}{*}{ 備 考 } \\
\hline & & & $\begin{array}{c}\text { 酸素消費量 } \\
\text { (站) }\end{array}$ & $\begin{array}{l}\text { 﨎生炭酸 } \\
\text { 斯 量 } \\
\text { (站) }\end{array}$ & $\begin{array}{c}\text { 每䣶一時間 } \\
\text { 酸素消費量 } \\
\text { (埕) }\end{array}$ & & & \\
\hline \multicolumn{9}{|c|}{ 白 } \\
\hline $18 / 1$ & $24^{\circ}$ & 153 & 186.10 & 132.00 & 1216.31 & 0.709 & & Pro. \\
\hline $30 / 1 /$ & 24 & 154 & 209.03 & 148.00 & 1357.34 & 0.708 & & " \\
\hline $18 / 1$ & 24 & 152 & 163.18 & 120.00 & 1073.58 & 0.735 & & Met. \\
\hline $22 / \prime \prime$ & 24 & 152 & 177.92 & 131.20 & 1170.55 & 0.737 & & $" \prime$ \\
\hline \multirow{2}{*}{ 平 均 } & & 154 & 197.57 & 140.00 & 1286.83 & 0.709 & & Pro. \\
\hline & & 152 & 170.55 & 125.60 & 1122.07 & 0.736 & -12.8 & Met. \\
\hline $23 /$ II & \multicolumn{8}{|c|}{ 卵 巣 剔 出 } \\
\hline $3 /$ III & 24 & 150 & 174.62 & 129.30 & 1164.13 & 0.740 & +3.7 & \\
\hline $8 / 11$ & 24 & 150 & 174.14 & 129.50 & 1160.95 & 0.744 & +3.4 & \\
\hline \multicolumn{9}{|c|}{ プロラン A. B. 注射開始 } \\
\hline $13 / " \prime$ & 24 & 149 & 172.49 & 133.00 & 1157.65 & 0.771 & +3.1 & \\
\hline $18 / " \prime$ & 24 & 146 & 154.65 & 118.00 & 1059.28 & 0.763 & -5.5 & \\
\hline $23 / 11$ & 24 & 148 & 163.23 & 124.10 & 1102.89 & 0.760 & -1.7 & \\
\hline $28 / 11$ & 24 & 151 & 162.36 & 124.00 & 1075.25 & 0.763 & -4.1 & \\
\hline $2 / \mathrm{IV}$ & 24 & 150 & 167.84 & 127.60 & 1189.93 & 0.760 & +6.0 & \\
\hline $7 / 11$ & 24 & 153 & 156.50 & 119.60 & 1022.84 & 0.764 & -8.8 & \\
\hline \multicolumn{9}{|c|}{ 白 鼠 4 9 $\quad$ (對照) } \\
\hline $10 / I$ & 24 & 151 & 196.81 & 140.00 & 1303.42 & 0.711 & & Oest. \\
\hline $14 / " 1$ & 24 & 153 & 176.09 & 142.00 & 1150.90 & 0742 & & Di. \\
\hline $8 /$ II & 24 & 165 & 197.77 & 146.00 & 1198.57 & 0.736 & & Met. \\
\hline $14 / " \prime$ & 24 & 163 & 201.14 & 144.00 & 1234.00 & 0.715 & & Oest. \\
\hline \multirow{2}{*}{ 平均 } & & 156 & 198.98 & 142.00 & 1268.71 & 0.713 & & Oest. Pro. \\
\hline & & 159 & 186.93 & 145.00 & 1174.74 & 0.739 & -7.4 & Met. Di. \\
\hline $19 / \mathbb{I I}$ & \multicolumn{8}{|c|}{ 卵巢 剔 出 } \\
\hline $27 / 11$ & 24 & 157 & 182.66 & 139.40 & 1163.45 & 0.763 & -0.9 & \\
\hline $3 /$ III & 24 & 152 & 175.92 & 133.70 & 1157.39 & 0.760 & -1.4 & \\
\hline $9 / / 1$ & 24. & 159 & 182.94 & 134.50 & 1150.59 & 0.735 & -2.0 & \\
\hline $14 / / 1$ & 24 & $157^{\circ}$ & 176.37 & 130.00 & 1123.37 & 0.737 & -4.3 & \\
\hline $19 / " 1$ & 24 & 157 & 166.49 & 126.00 & 1060.47 & 0.756 & -9.7 & \\
\hline $24 / " \prime$ & 24 & 154 & 177.99 & 133.20 & 1155.80 & 0.748 & -1.6 & \\
\hline $29 / .1$ & 24 & 144 & 169.06 & 126.30 & 1174.04 & 0.747 & 0 & \\
\hline $3 / I V$ & 24 & 143 & 156.70 & 116.40 & 1095.80 & 0.743 & -6.7 & \\
\hline
\end{tabular}


萧 三 关

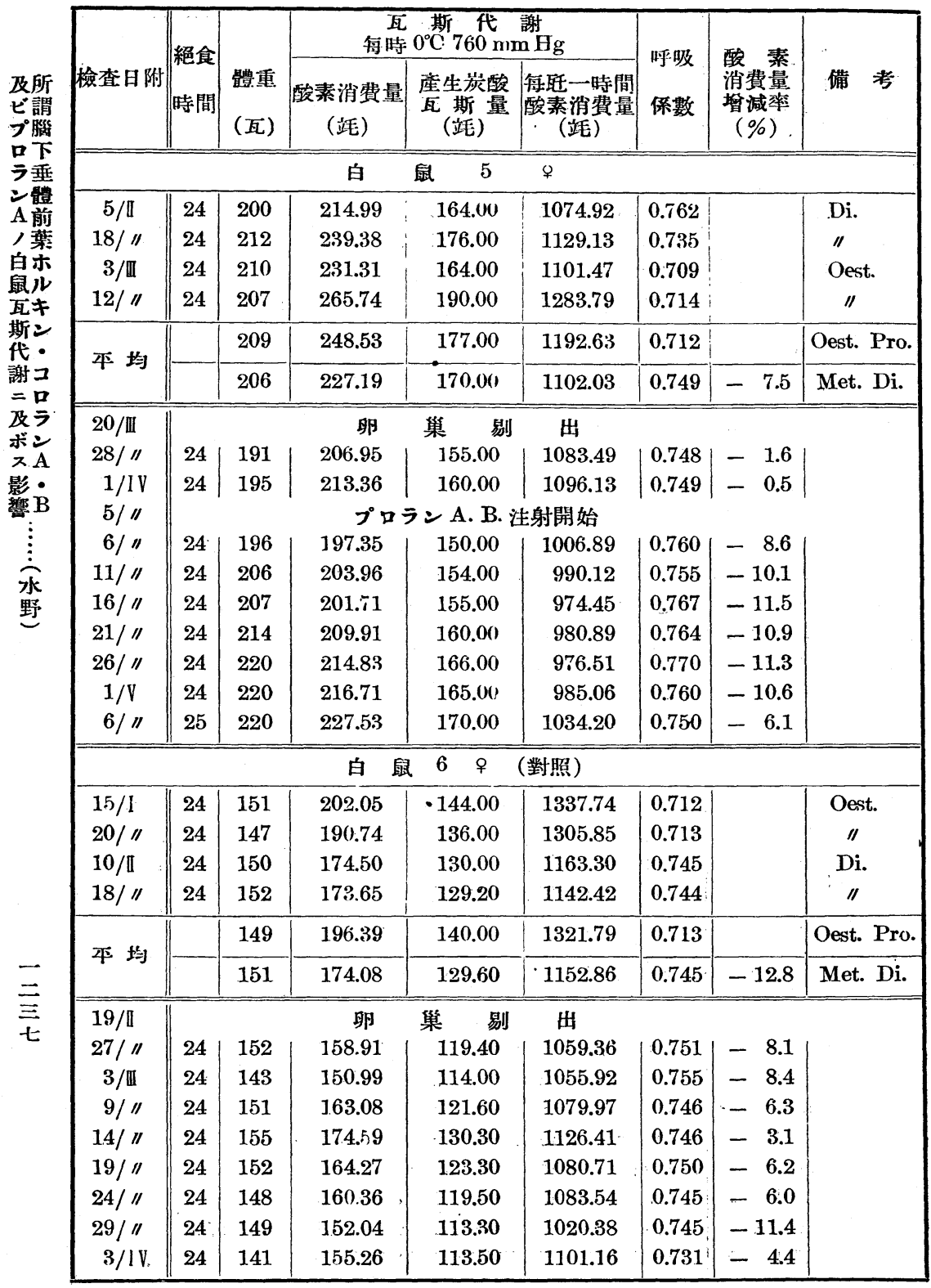


苐四表

\begin{tabular}{|c|c|c|c|c|c|c|c|c|}
\hline \multirow[b]{2}{*}{ 检查日附 } & \multirow{2}{*}{ 絕食 } & \multirow[b]{2}{*}{$\begin{array}{l}\text { 體重 } \\
\text { (瓦) }\end{array}$} & \multicolumn{3}{|c|}{ 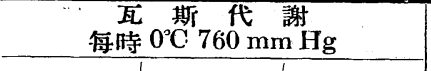 } & \multirow[b]{2}{*}{$\begin{array}{l}\text { 呼吸 } \\
\text { 係數 }\end{array}$} & \multirow[b]{2}{*}{$\begin{array}{c}\text { 酸素 } \\
\text { 消費量 } \\
\text { 坆減恝 } \\
(\%)\end{array}$} & \multirow[b]{2}{*}{ 備 考 } \\
\hline & & & $\mid \begin{array}{c}\text { 酸素消費量 } \\
\text { (䇃) }\end{array}$ & $\begin{array}{c}\text { 產生炭酸 } \\
\text { 斯 量 } \\
\text { (站) }\end{array}$ & \begin{tabular}{|c} 
每䏕一時間 \\
酸素消費量 \\
(站)
\end{tabular} & & & \\
\hline \multicolumn{9}{|c|}{ 白 } \\
\hline $6 / I$ & 24 & 243 & 306.50 & 218.00 & 1261.31 & 0.709 & & Oest. \\
\hline $21 / / 1$ & 24 & 230 & 284.08 & 200.00 & 1235.11 & 0.704 & & Pro. \\
\hline $8 / \mathbb{I I}$ & 24 & 238 & 253.23 & 188.00 & 1063.99 & 0.742 & & Di. \\
\hline $18 / " \prime$ & 24 & 241 & 273.12 & 200.00 & 1133.27 & 0.732 & & $" 1$ \\
\hline \multirow{2}{*}{ 平 均 } & & 237 & 295.29 & 209.00 & 1248.21 & 0.707 & & Pro. Oest. \\
\hline & & 240 & 263.18 & 194.00 & 1098.63 & 0.737 & -11.9 & Met. Di. \\
\hline $22 /$ II & \multicolumn{8}{|c|}{$\begin{array}{lll}\text { 巢 卵 剔 出 }\end{array}$} \\
\hline $30 / 11$ & 24 & 233 & 241.51 & 180.00 & 1036.52 & 0.744 & $-\quad 5.6$ & \\
\hline $4 / I V$ & 24 & 216 & 226.40 & 168.00 & 1048.15 & 0.742 & -4.5 & \\
\hline $8 / 11$ & \multicolumn{8}{|c|}{ プロランA. B. 注射開始 } \\
\hline $9 / / 1$ & 24 & 219 & 202.65 & 154.00 & 925.33 & 0.760 & -15.7 & \\
\hline $14 / \prime \prime$ & 24 & 234 & 218.75 & 168.00 & 934.80 & 0.768 & -14.9 & \\
\hline $19 / \|$ & 25 & 233 & 223.45 & 172.00 & 959.09 & 0.766 & -12.7 & \\
\hline $24 / 1 /$ & 24 & 237 & 227.13 & .176 .00 & 958.33 & 0.773 & -12.7 & \\
\hline $29 / 1 /$ & 24 & 233 & & & & & & \\
\hline $4 / V$ & 26 & 236 & 225.07 & 174.00 & 953.71 & 0.775 & -13.1 & \\
\hline $9 / 1 /$ & 23 & 240 & 262.02 & 196.00 & 1091.76 & 0.747 & -0.6 & \\
\hline \multicolumn{9}{|c|}{ 白 $\quad$ 鼠 8 \% $\quad$ (對照) } \\
\hline $15 / 1$ & 24 & 150 & 206.59 & 148.00 & 1377.26 & 0.718 & & Pro. \\
\hline $21 / \|$ & 24 & 150 & 186.67 & 138.00 & $1 \approx 44.45$ & 0.739 & & Met. \\
\hline $4 / \pi$ & 24 & 149 & 201.15 & 144.00 & 1349.76 & 0.715 & & Pro. \\
\hline $16 / " /$ & 24 & 150 & 175.46 & 129.00 & 1169.75 & 0.740 & & Di. \\
\hline \multirow{2}{*}{ 平均 } & & 150 & 203.87 & 146.00 & 1363.51 & 0.717 & & Pro. Oest. \\
\hline & & 150 & 181.07 & 133.00 & 1207.10 & 0.74 .0 & -11.4 & Met. Di. \\
\hline $21 / \mathbb{I}$ & \multicolumn{8}{|c|}{$\begin{array}{llll}\text { 沺 巢 剔 出 }\end{array}$} \\
\hline $1 / \mathbb{I I}$ & 24 & 150 & 175.96 & 132.00 & 1173.96 & 0.750 & -2.9 & \\
\hline $6 / 11$ & 24 & 147 & 165.79 & 124.70 & 1127.79 & 0.752 & -6.5 & \\
\hline $11 / / 1$ & 24 & 150 & 174.00 & 131.20 & 1160.00 & 0.754 & -3.9 & \\
\hline $16 / " \prime$ & 25 & 150 & 169.58 & 127.20 & 1130.56 & 0.750 & -6.3 & \\
\hline $21 / \prime \prime$ & 24 & 155 & 174.89 & 130.00 & 1128.32 & 0.743 & -6.5 & \\
\hline $26 / " \prime$ & 24 & 157 & 175.97 & 131.00 & 1120.83 & 0.745 & -7.1 & \\
\hline $31 / / 1$ & 25 & 155 & 184.11 & 137.80 & 1187.83 & 0.748 & -1.5 & \\
\hline $5 /$ IV & 24 & 155 & 182.32 & 136.10 & 1176.22 & 0.746 & -2.5 & \\
\hline
\end{tabular}


第五雯

\begin{tabular}{|c|c|c|c|c|c|c|c|c|c|}
\hline & \multirow[b]{2}{*}{ 檢查日附 } & \multirow{2}{*}{ 絕食 } & \multirow[b]{2}{*}{$\begin{array}{l}\text { 體重 } \\
\text { (丽) }\end{array}$} & \multicolumn{3}{|c|}{$\begin{array}{c}\text { 瓦 斯 代 謝 } \\
\text { 每時 } 0^{\circ} \mathrm{C} 760 \mathrm{~mm} \mathrm{Hg}\end{array}$} & \multirow{2}{*}{$\begin{array}{l}\text { 呼吸 } \\
\text { 保數 }\end{array}$} & \multirow{2}{*}{$\begin{array}{c}\text { 酸素 } \\
\text { 消費量 } \\
\text { 墳減率 } \\
(\%)\end{array}$} & \multirow[b]{2}{*}{ 備 宩 } \\
\hline & & & & $\mid \begin{array}{c}\text { 酸素消費量 } \\
\text { (坑芯) }\end{array}$ & $\begin{array}{c}\text { 產生炭酸 } \\
\text { 瓦斯量 } \\
\text { (筧) }\end{array}$ & $\begin{array}{l}\text { 每呧一時間 } \\
\text { 酸素消費量 } \\
\text { (让) }\end{array}$ & & & \\
\hline & \multicolumn{9}{|c|}{ 白 } \\
\hline 簎 & $13 / \mathbb{I}$ & 24 & 166 & 187.33 & 139.00 & 1128.48 & 0.743 & & Met. \\
\hline 儿葉 & $24 / 1 /$ & 24 & 166 & 181.51 & 132.00 & 1093.43 & 0.727 & & Di. \\
\hline 白ホ & $1 /$ III & 24 & 168 & 212.54 & 152.00 & 1265.10 & 0.714 & & Pro. \\
\hline 瓦七 & $15 / / /$ & 24 & 179 & 215.07 & 152.00 & 1201.51 & 0.708 & & " \\
\hline 斯之 & \multirow{2}{*}{ 本均 } & & 174 & 213.81 & 152.00 & 1233.31 & 0.711 & & Pro. Oest. \\
\hline $\begin{array}{l}\text { 謝プ } \\
=\square\end{array}$ & & & 166 & 184.42 & 136.00 & 1110.96 & 0.735 & -9.9 & Met. Di. \\
\hline 及ラ & $22 /$ III & \multicolumn{8}{|c|}{$\begin{array}{lll}\text { 巣 剔 出 } & \text { 剔 }\end{array}$} \\
\hline $\begin{array}{l}\text { ボン } \\
\text { スA }\end{array}$ & $30 / / 1$ & 24 & 160 & 170.84 & 128.00 & \begin{tabular}{|l}
1067.75 \\
\end{tabular} & 0.750 & -3.8 & \\
\hline 影・ & $4 / \mathrm{IV}$ & 24 & 162 & 174.82 & 130.00 & 1079.07 & 0.744 & -2.8 & \\
\hline \multicolumn{10}{|c|}{ プロラン A. B. 注射開始 } \\
\hline : & $9 / / 1$ & 24 & 170 & 185.31 & 140.00 & 1090.05 & 0.755 & -1.8 & \\
\hline$\widehat{-2 x}$ & $14 / / /$ & 24 & 178 & 168.11 & 128.00 & 944.42 & 0.761 & -14.9 & \\
\hline 野 & $19 / / /$ & 25 & 179 & 174.67 & 134.00 & 975.80 & 0.770 & -12.1 & \\
\hline & $24 / / 1$ & 24 & 183 & 178.02 & 137.00 & 972.80 & 0.770 & -12.4 & \\
\hline & $29 / 1 /$ & 24 & 185 & & & & & & \\
\hline & $4 / V$ & 24 & 187 & 179.37 & 138.00 & 959.19 & 0.771 & -13.6 & \\
\hline & $9 / 11$ & 21 & 190 & 208.55 & 156.00 & 1097.64 & 0.745 & -1.1 & \\
\hline & \multicolumn{9}{|c|}{ 白 鼠 10 ～（對照） } \\
\hline & $14 /$ II & 24 & 161 & 182.67 & 138.00 & 1134.58 & 0.754 & & Met. \\
\hline & $19 / "$ & 24 & 164 & 191.23 & 140.00 & 1166.00 & 0.732 & & Di. \\
\hline & $23 / 1 /$ & 24 & 170 & 205.48 & 140.00 & 1208.70 & 0.710 & & Oest. \\
\hline & $6 /$ III & 24 & 173 & 219.63 & 157.00 & 1269.55 & 0.716 & & "I \\
\hline & \multirow{2}{*}{ 平均 } & & 172 & 212.56 & 149.00 & 1239.13 & 0.713 & & Oest. Pro. \\
\hline & & & 163 & 186.95 & 139.00 & 1150.26 & 0.743 & -7.1 & Met. Di. \\
\hline$\equiv$ & $14 / \mathbb{I I}$ & \multicolumn{8}{|c|}{ 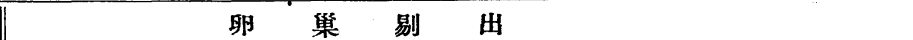 } \\
\hline 九 & $22 / 11$ & 24 & 154 & 154.76 & 114.70 & 1004.92 & 0.741 & -12.6 & \\
\hline & $27 / 1 /$ & 24 & 155 & 176.64 & 131.60 & 1143.96 & 0.745 & -0.5 & \\
\hline & $1 / I V$ & 24 & 158 & 178.06 & 133.60 & 1126.97 & 0.750 & -2.0 & \\
\hline & $6 / 1 /$ & 24 & 64 & 174.05 & 130.40 & 1061.25 & 0.743 & -7.7 & \\
\hline & $11 / \prime \prime$ & 24 & 165 & 179.09 & 135.80 & 1085.37 & 0.758 & -5.6 & \\
\hline & $16 / / 1$ & 24 & 170 & 183.94 & $1: 36.30$ & 1082.00 & 0.741 & -5.9 & \\
\hline & $21 / "$ & 24 & 173 & 199.64 & 148.00 & 1153.99 & 0.741 & 0 & \\
\hline & $26 / \|$ & 24 & 178 & 203.84 & 152.00 & 1145.18 & 0.745 & -0.4 & \\
\hline
\end{tabular}


第 六表

\begin{tabular}{|c|c|c|c|c|c|c|c|c|}
\hline \multirow[b]{2}{*}{ 檢查日附 } & \multirow{2}{*}{ 絕食 } & \multirow[b]{2}{*}{$\begin{array}{l}\text { 體重 } \\
\text { (瓦) }\end{array}$} & \multicolumn{3}{|c|}{$\begin{array}{c}\text { 瓦 斯 代 謝 } \\
\text { 每時 } 0^{\circ} \mathrm{C} 760 \mathrm{~mm} \mathrm{Hg}\end{array}$} & \multirow{2}{*}{$\begin{array}{l}\text { 呼吸 } \\
\text { 保數 }\end{array}$} & \multirow[b]{2}{*}{$\begin{array}{c}\text { 酸素 } \\
\text { 渻費 } \\
\text { 增減率 } \\
(\%)\end{array}$} & \multirow[b]{2}{*}{ 備 考 } \\
\hline & & & \begin{tabular}{|c|} 
酸素消費量 \\
(靖)
\end{tabular} & $\begin{array}{l}\text { 產生炭酸 } \\
\text { 斯 量 } \\
\text { (站) }\end{array}$ & $\begin{array}{c}\text { 每䣶一時間 } \\
\text { 酸素消量量 } \\
\text { (站) }\end{array}$ & & & \\
\hline \multicolumn{9}{|c|}{ 白 } \\
\hline $1 /$ 任 & 24 & 165 & 173.32 & 130.00 & 1050.41 & 0.750 & & Di. \\
\hline $6 / 4$ & 24 & 171 & 189.07 & 135.00 & 1105.68 & 0.714 & & Oest. \\
\hline $11 / / /$ & 24 & 178 & 210.53 & 150.00 & 1182.73 & 0.709 & & / \\
\hline $22 / 1 /$ & 24 & 164 & 180.54 & 134.00 & 1100.87 & 0.741 & & Di. \\
\hline \multirow{2}{*}{ 平均 } & & 175 & 199.80 & 143.00 & 1144.21 & 0.712 & & Pro. Oest. \\
\hline & & $\cdot 165$ & 176.93 & 132.00 & 1075.64 & 0.746 & -5.9 & Met. Di. \\
\hline $31 /$ III & \multicolumn{8}{|c|}{ 卵 巢 剔 出 } \\
\hline $8 / I V$ & 24 & 154 & 158.94 & 120.00 & 1032.06 & 0.755 & -4.0 & \\
\hline $13 / / /$ & 24 & 161 & 166.49 & 124.00 & | 1034.12 & 0.750 & -3.8 & \\
\hline $17 / 1 /$ & \multicolumn{8}{|c|}{ プロラン A. B. 注射開始 } \\
\hline $18 / / 1$ & 24 & 167 & 166.81 & 130.00 & | 998.87 & 0.779 & - 7.1 & \\
\hline & 23 & 170 & 162.45 & 124.00 & 955.56 & 0.765 & -11.1 & \\
\hline \multicolumn{9}{|l|}{$28 / "$} \\
\hline $3 / V$ & 24 & 170 & 168.99 & 128.00 & 994.10 & 0.762 & -7.5 & \\
\hline $8 / 1 /$ & 24 & 171 & 167.04 & 128.00 & 976.81 & 0.765 & -9.1 & \\
\hline $13 / \|$ & 24 & 174 & 171.15 & 132.00 & 983.54 & 0.768 & -5.8 & \\
\hline $18 / "$ & 24 & 171 & 201.97 & 148.00 & 1181.13 & 0.735 & +9.8 & \\
\hline \multicolumn{9}{|c|}{ 白 鼠 12 \% . (對照) } \\
\hline $26 / \mathbb{I}$ & 24 & 163 & 197.24 & 140.00 & 1210.03 & 0.709 & & Pro. \\
\hline $2 / \mathbb{I I}$ & 24 & 165 & 195.20 & 138.50 & 1181.95 & 0.710 & & Oest. \\
\hline $12 / / /$ & 24 & 155 & 176.24 & 125.20 & 1078.95 & 0.746 & & Met. \\
\hline $17 / \prime \prime$ & 24 & 165 & 189.20 & 142.00 & 1146.71 & 0.750 & & Di. \\
\hline \multirow{2}{*}{ 平 均 } & & 164 & 196.13 & 139.25 & 1195.99 & 0.710 & & Pro. Oest. \\
\hline & & 160 & 178.22 & 133.10 & 1112.83 & $0: 748$ & -6.9 & Met. Di. \\
\hline $20 / \mathbb{I I}$ & \multicolumn{8}{|c|}{$\begin{array}{lll}\text { 卵 巢 剔 出 }\end{array}$} \\
\hline $28 / \|$ & 24 & 351 & 173.57 & 129.60 & 1156.10 & 0.746 & +3.8 & \\
\hline $2 / I V$ & 24 & 161 & 186.06 & 138.10 & 1155.67 & 0.742 & +3.8 & \\
\hline $7 / / /$ & 24 & 161 & 178.17 & 133.40 & 1106.67 & 0.749 & -0.5 & \\
\hline $12 / 11$ & 24 & 170 & 194.26 & 144.00 & 1142.72 & 0.743 & +2.6 & \\
\hline $17 / / 1$ & 24 & 169 & 191.18 & 140.00 & 1124.60 & 0.747 & +1.0 & \\
\hline $22 / 1 /$ & 24 & 176 & 194.27 & 144.00 & 1103.81 & 0.741 & -0.8 & \\
\hline $27 / 11$ & 24 & 179 & 204.56 & 152.00 & 1142.81 & 0.743 & +2.6 & \\
\hline $2 / V$ & 24 & 182 & 210.79 & 158.00 & 1158.10 & 0.749 & +4.0 & \\
\hline
\end{tabular}




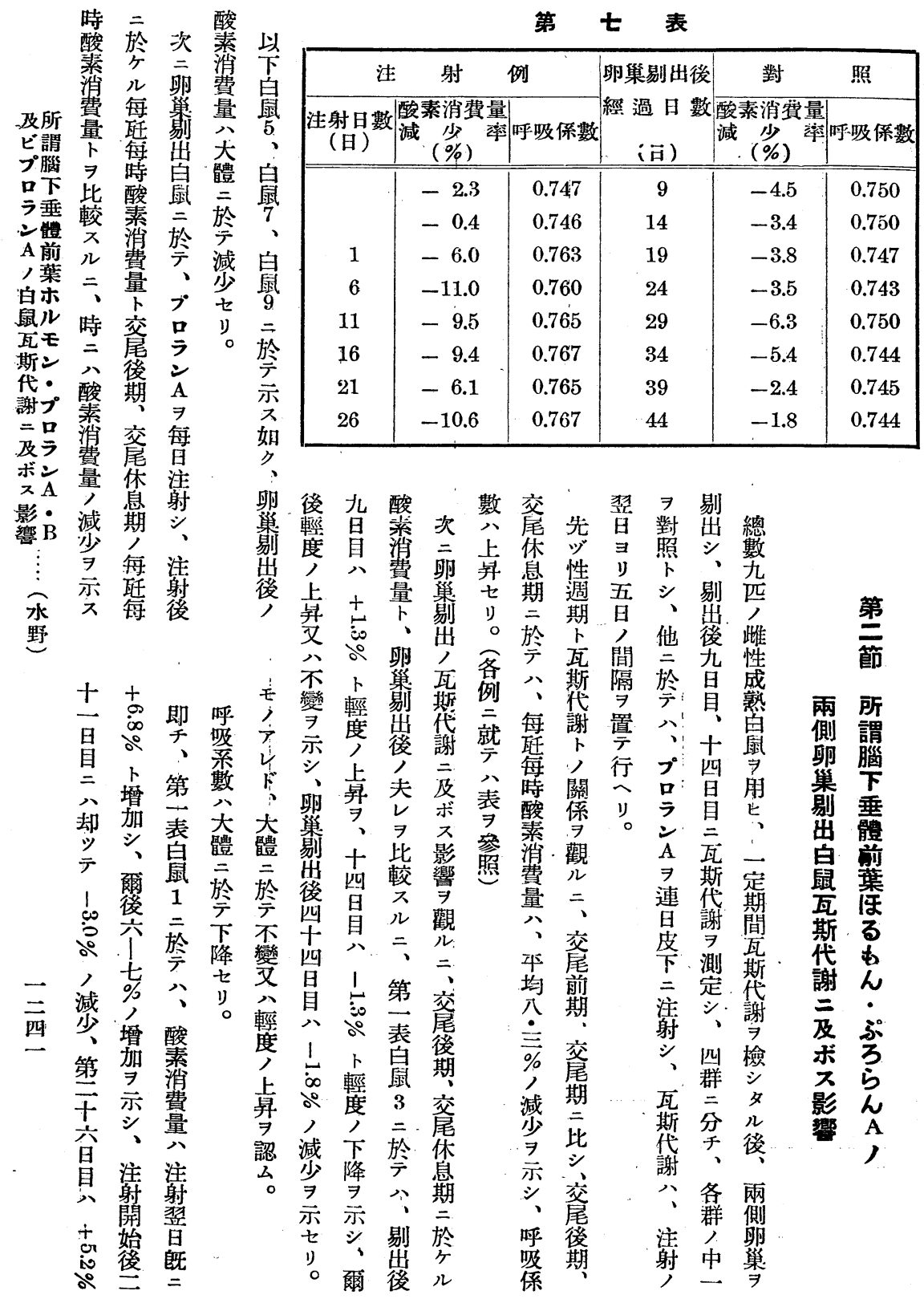




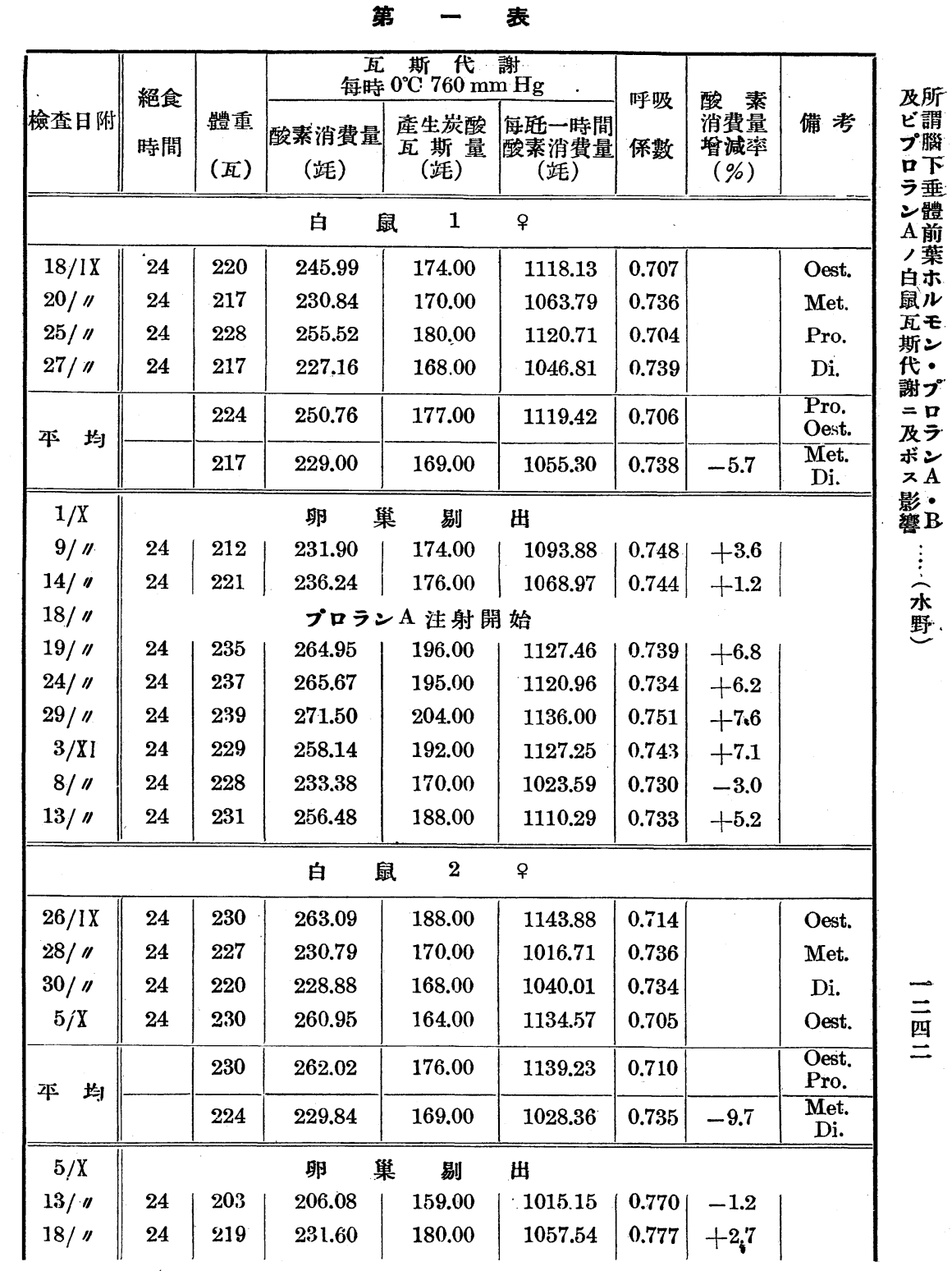




\begin{tabular}{|c|c|c|c|c|c|c|c|c|c|}
\hline \multirow{3}{*}{ 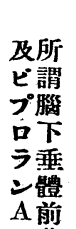 } & \multirow[b]{2}{*}{ 檢查日附 } & \multirow{2}{*}{$\begin{array}{l}\text { 絕食 } \\
\text { 時間 }\end{array}$} & \multirow[b]{2}{*}{$\begin{array}{l}\text { 體重 } \\
\text { (桼) }\end{array}$} & \multicolumn{3}{|c|}{$\begin{array}{c}\text { 瓦 斯 代 謝 } \\
\text { 每時 } 0^{\circ} \mathrm{C}: 760 \mathrm{~mm} \mathrm{Hg} \\
\end{array}$} & \multirow{2}{*}{$\begin{array}{l}\text { 呼吸 } \\
\text { 保數 }\end{array}$} & \multirow{2}{*}{$\begin{array}{l}\text { 酸 素 } \\
\text { 消費量 } \\
\text { 翼娍輩 } \\
(\%)\end{array}$} & \multirow[b]{2}{*}{ 備 考 } \\
\hline & & & & $\mid$\begin{tabular}{c|} 
酸素消費量 \\
(竨)
\end{tabular} & $\begin{array}{l}\text { 產生炭酸 } \\
\text { 斯 量 } \\
\text { (站) }\end{array}$ & $\mid \begin{array}{c}\text { 每聖一時間 } \\
\text { 酸素消費量 } \\
\text { (站) }\end{array}$ & & & \\
\hline & $22 / X$ & \multicolumn{8}{|c|}{ プロランA 注射開始 } \\
\hline 皇 & $23 / 1 /$ & 24 & 230 & 246.18 & 180.00 & \begin{tabular}{|l|l} 
& 1070.36
\end{tabular} & 0.731 & +4.0 & \\
\hline 鼠ル & $28 / / 1$ & 24 & 243 & 258.39 & 190.00 & 1063.32 & 0.735 & +3.3 & \\
\hline 㼛モ & $2 / \mathrm{XI}$ & 24 & 237 & 248.59 & 184.00 & 1048.88 & 0.740 & +1.9 & \\
\hline 代・ & $7 / 11$ & 24 & 238 & 245.84 & 182.00 & 1032.92 & 0740 & +0.4 & \\
\hline $\begin{array}{l}\text { 謝プ } \\
=\text { 吕 }\end{array}$ & $12 / \|$ & 24 & 245 & 250.44 & 184.00 & 1022.19 & 0.734 & -0.5 & \\
\hline 及ラ & $17 / / /$ & 24 & 247 & 258.91 & 195.00 & 1048.21 & 0.752 & +1.9 & \\
\hline $\begin{array}{l}\text { 影・ } \\
\end{array}$ & \multicolumn{9}{|c|}{ 白 鼠 3 ㅇ (對照) } \\
\hline & $5 / I X$ & 24 & 168 & 220.13 & 156.00 & 1310.30 & 0.708 & & Oest. \\
\hline & $10 / / /$ & 24 & 173 & 205.26 & 152.00 & 1186.48 & 0.740 & & Met. \\
\hline 承 & $15 / / 1$ & 24 & 176 & 217.99 & 154.00 & 1238.61 & 0.706 & & Oest. \\
\hline 野 & $25 / 11$ & 24 & 180 & 210.02 & 156.00 & 1166.79 & 0.742 & & Di. \\
\hline & \multirow{2}{*}{ 平 均 } & & 172 & 219.06 & 155.00 & 1274.46 & 0.707 & & $\begin{array}{l}\text { Pro. } \\
\text { Oest. }\end{array}$ \\
\hline & & & 174 & 207.64 & 154.00 & 1176.64 & 0.741 & -7.6 & $\begin{array}{l}\text { Met. } \\
\text { Di. }\end{array}$ \\
\hline & $5 / X$ & \multicolumn{8}{|c|}{$\begin{array}{lll}\text { 卵 巢 剔 出 }\end{array}$} \\
\hline & $13 / 1 /$ & 24 & 170 & 202.83 & 152.00 & \begin{tabular}{|l|l|} 
& 1193.09
\end{tabular} & 0.749 & \multicolumn{2}{|l|}{+1.3} \\
\hline & $18 / / /$ & 24 & 171 & 198.48 & 148.00 & $1160^{\prime} 69$ & 0.745 & \multicolumn{2}{|l|}{-1.3} \\
\hline & $23 / X$ & 24 & 177 & 208.31 & 156.00 & 1176.91 & 0.748 & \multicolumn{2}{|l|}{+0} \\
\hline & $28 / / 1$ & 24 & 185 & 221.24 & 164.00 & 1195.87 & 0.738 & \multicolumn{2}{|l|}{+1.6} \\
\hline$\rightarrow$ & $2 / X I$ & 24 & 190 & 221.67 & 170.00 & 1198.28 & 0.746 & \multicolumn{2}{|l|}{+1.8} \\
\hline 二 & $7 / 11$ & 24 & 197 & 231.87 & 174.60 & 1177.02 & 0.750 & \multicolumn{2}{|l|}{0} \\
\hline$\equiv$ & $12 / " \prime$ & 24 & 197 & 236.05 & 178.00 & 1198.24 & 0.750 & \multicolumn{2}{|l|}{+1.8} \\
\hline & $17 / / \prime$ & 24 & 202 & 233.29 & 182.00 & 1154.90 & 0.779 & \multicolumn{2}{|l|}{-1.8} \\
\hline
\end{tabular}


第二表

\begin{tabular}{|c|c|c|c|c|c|c|c|c|}
\hline \multirow[b]{2}{*}{ 憸查日附 } & \multirow{2}{*}{$\begin{array}{l}\text { 絕食 } \\
\text { 時間 }\end{array}$} & \multirow[b]{2}{*}{$\begin{array}{l}\text { 體重 } \\
\text { （丽） }\end{array}$} & \multicolumn{3}{|c|}{$\begin{array}{c}\text { 丽 斯 代 謝 } \\
\text { 偟時 } 0^{\circ} \mathrm{C} 760 \mathrm{~mm} \mathrm{Hg} \\
\end{array}$} & \multirow[b]{2}{*}{$\begin{array}{l}\text { 呼吸 } \\
\text { 係數 }\end{array}$} & \multirow[b]{2}{*}{$\begin{array}{l}\text { 酸素 } \\
\text { 消費量 } \\
\text { 垻減率 } \\
(\%)\end{array}$} & \multirow[b]{2}{*}{ 備 考 } \\
\hline & & & \begin{tabular}{|c} 
酸素渻費量 \\
(站)
\end{tabular} & $\begin{array}{c}\text { 產生炭酸 } \\
\text { 瓦 斯 量 } \\
\text { (站) }\end{array}$ & $\left|\begin{array}{c}\text { 每聶一時間 } \\
\text { 酸素消費量 } \\
\text { (靖) }\end{array}\right|$ & & & \\
\hline \multicolumn{9}{|c|}{ 白 } \\
\hline $8 / X$ & 24 & 205 & 260.34 & 184.00 & 1269.93 & $0.70 b$ & & Oest. \\
\hline $18 / / /$ & 24 & 180 & 206.83 & 154.00 & 1149.03 & 0.744 & & Met. \\
\hline $21 / \|$ & 24 & 185 & 214.93 & 160.00 & 1161.78 & 0.744 & & Met. \\
\hline $25 / 11$ & 24 & 183 & 233.64 & 164.00 & 1276.67 & 0.701 & & Oest. \\
\hline \multirow{2}{*}{ 平 均 } & & 194 & 246.99 & 174.00 & 1273.30 & 0.704 & & $\begin{array}{l}\text { Pro. } \\
\text { Oest }\end{array}$ \\
\hline & & 183 & 210.88 & 157.00 & 1155.41 & 0.744 & -9.2 & $\begin{array}{l}\text { Met. } \\
\text { Di. }\end{array}$ \\
\hline $2 / X I$ & \multicolumn{8}{|c|}{ 卵巢 剔出 } \\
\hline $10 / / 1$ & 24 & 192 & 218.95 & 170.00 & 1140.37 & 0.776 & -1.3 & \\
\hline $15 / / 1$ & 24 & 191 & 216.71 & 164.00 & 1134.64 & 0.756 & -1.8 & \\
\hline \multicolumn{9}{|c|}{ ! プロランA 注 射開 始 } \\
\hline $20 / 11$ & 24 & 183 & 209.20 & .159 .00 & 1143.17 & 0.759 & -1.0 & \\
\hline $25 / 11$ & 24 & 175 & 199.54 & 154.00 & 1140.23 & 0.773 & -1.3 & \\
\hline $30 / / 1$ & 24 & 174 & 204.90 & 156.00 & 1177.59 & 0.760 & +1.9 & \\
\hline $5 / X \square$ & 24 & 180 & 207.03 & 158.00 & 1150.18 & 0.762 & -0.4 & \\
\hline $10 / / 1$ & 24 & 180 & 209.88 & 162.00 & 1165.99 & 0.770 & +0.9 & \\
\hline $15 / 1 /$ & 24 & 182 & 203.16 & 156.00 & 1116.27 & 0.766 & -3.3 & \\
\hline \multicolumn{9}{|c|}{ 白 鼠 5 \% (對照) } \\
\hline $9 / X$ & 24 & 179 & 223.21 & 158.00 & 1246.96 & 0.707 & & Oest. \\
\hline $16 / / 1$ & 24 & 190 & 232.69 & 164.00 & 1224.68 & 0.704 & & Pro. \\
\hline $21 / 1 "$ & 24 & 190 & 215.92 & 160.00 & 1136.40 & 0.742 & & Met. \\
\hline $26 / 1 /$ & 24 & 194 & ! 217.21 & 160.00 & 1119.61 & 0.734 & & Di. \\
\hline \multirow{2}{*}{ 平 均 } & & 185 & 227.95 & 161.00 & 1235.85 & 0.706 & . & $\begin{array}{l}\text { Pro. } \\
\text { Oest. }\end{array}$ \\
\hline & & 192 & 216.57 & 160.00 & 1128.01 & 0.738 & -8.7 & $\begin{array}{l}\text { Met. } \\
\text { Di. }\end{array}$ \\
\hline $2 / X I$ & \multicolumn{8}{|c|}{ ，卵巢，剔出 } \\
\hline $10 / " 1$ & 24 & 186 & 204.56 & 156.00 & \begin{tabular}{|l}
1099.80 \\
\end{tabular} & 0.760 & -2.5 & \\
\hline $15 / \prime \prime$ & 24 & 186 & 198.65 & 152.00 & 1068.03 & 0.765 & -5.3 & \\
\hline $20 / 11$ & 24 & 182 & 197.23 & 148.00 & 1083.65 & 0.750 & -3.9 & \\
\hline $25 / \prime \prime$ & 24 & 187 & 221.19 & 168.00 & 1182.82 & 0.756 & +4.8 & \\
\hline $30 / " 1$ & 24 & 188 & 208.65 & 154.00 & 1109.84 & 0.741 & -1.6 & \\
\hline $5 / \mathrm{X}$ & 24 & 185 & 187.47 & 144.00 & 1024.13 & 0.760 & -9.2 & \\
\hline $10 / / /$ & 24 & 184 & 201.08 & 152.00 & 1092.85 & 0.755 & -3.1 & \\
\hline $15 / n$ & 24 & 180 & 214.15 & 162.00 & 1189.74 & 0.759 & +5.4 & \\
\hline
\end{tabular}




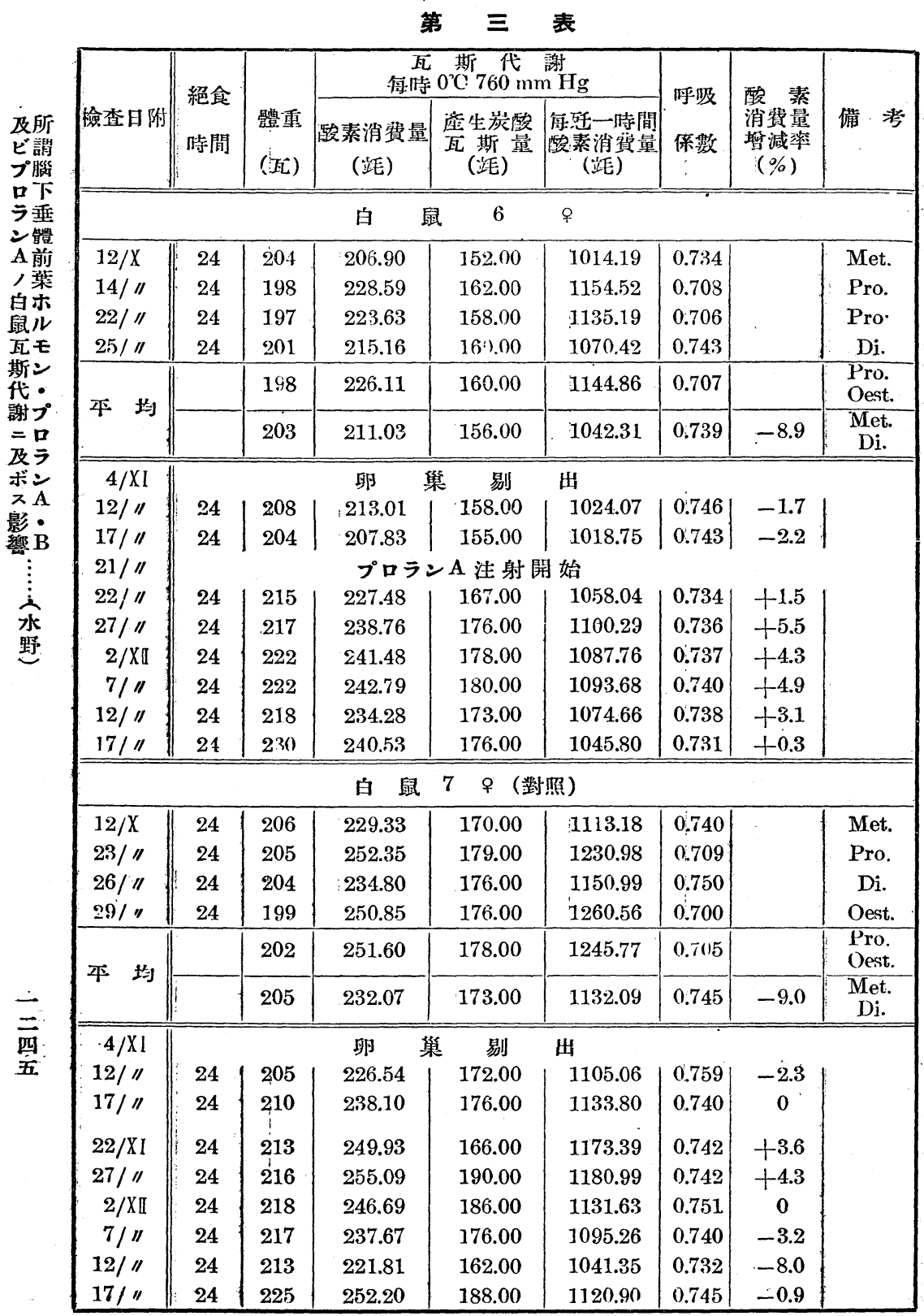


第四震

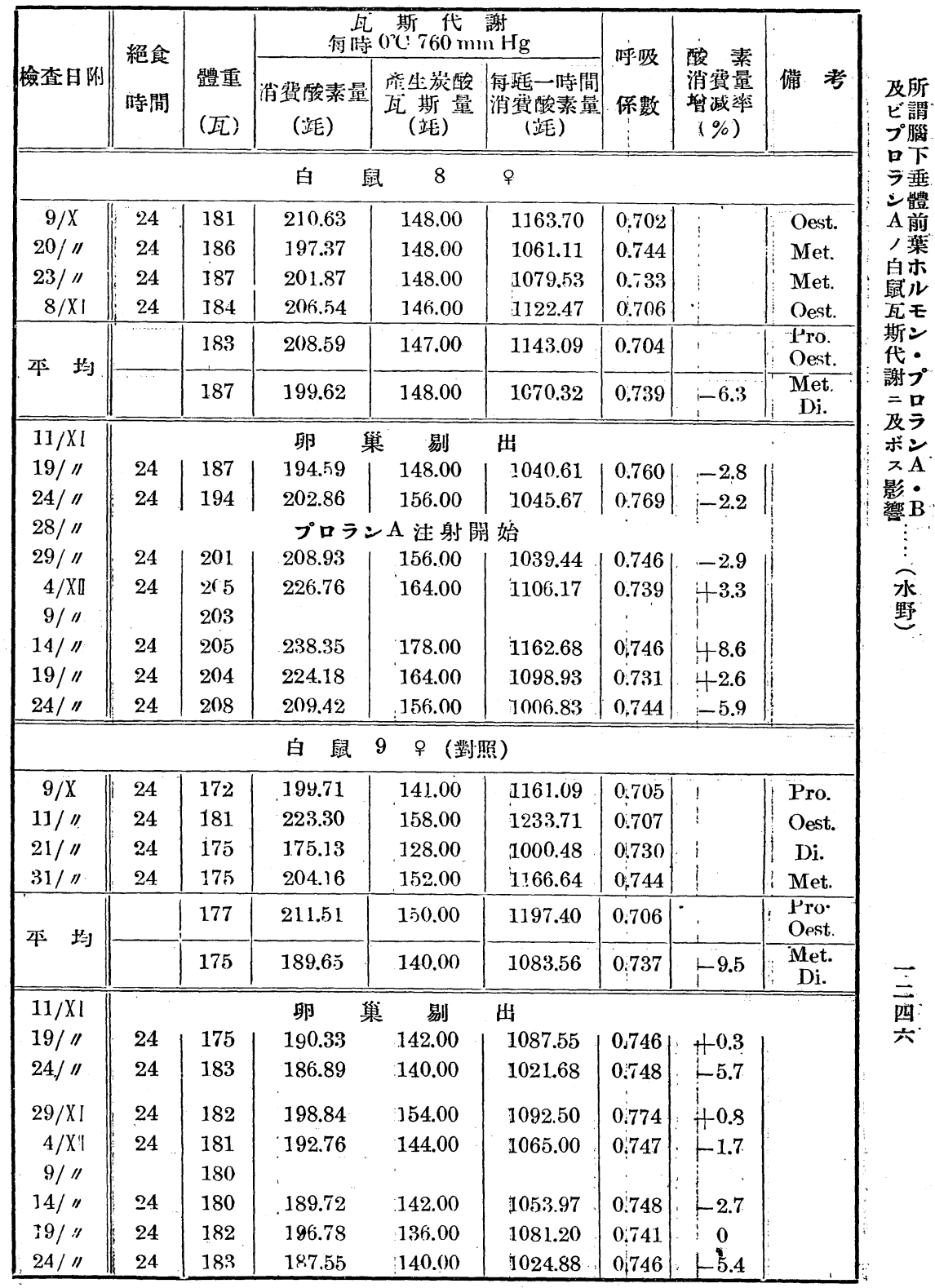




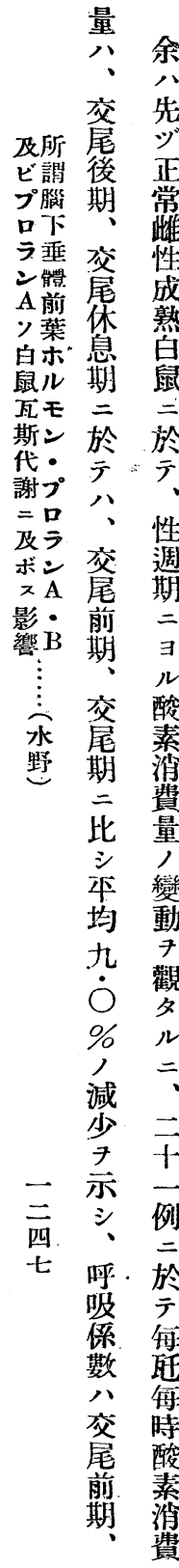

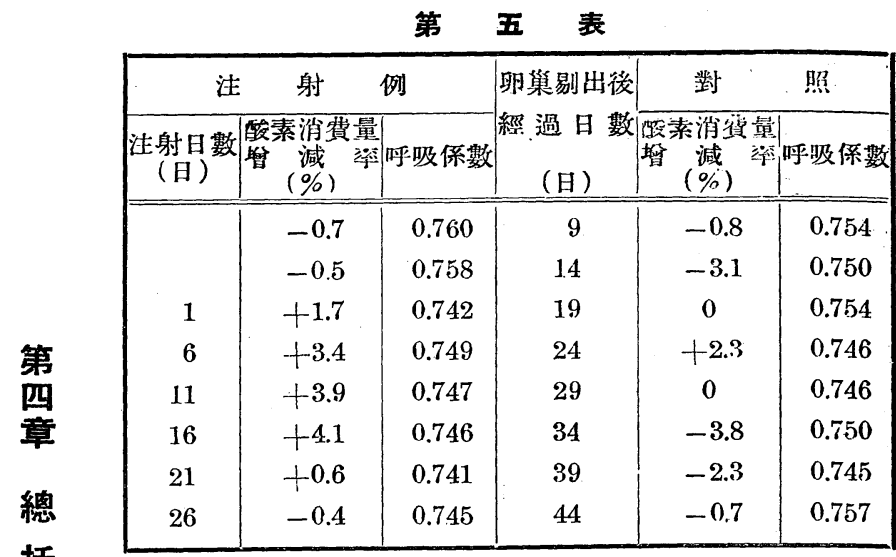

括

並

二
考

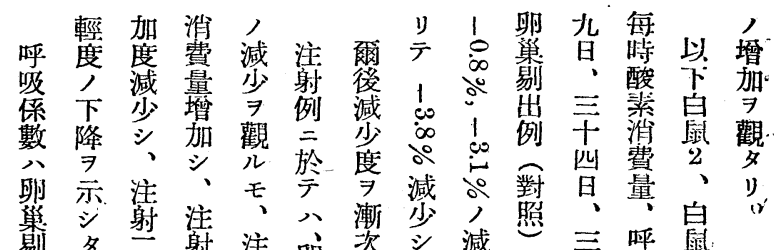

按

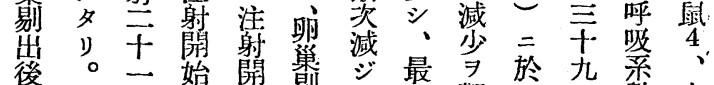

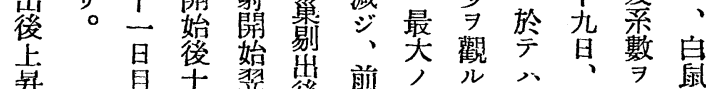

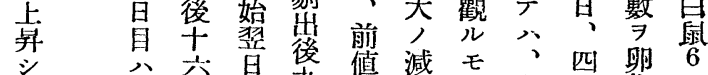

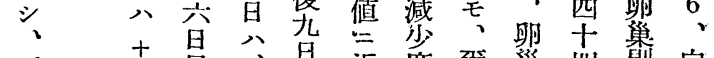

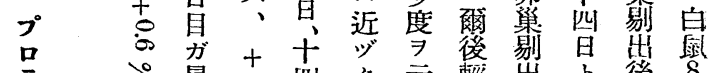

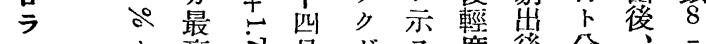

シ 卜高

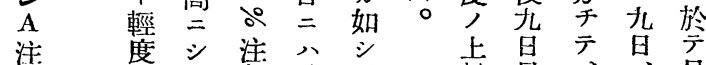

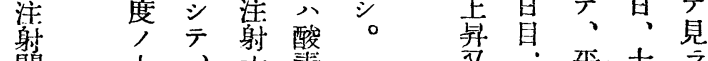

上、分美文十斥十今

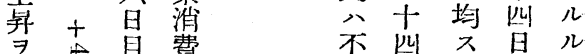

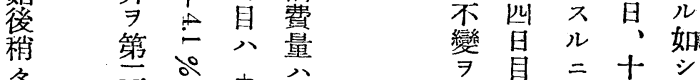

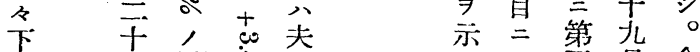

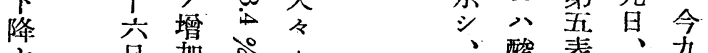

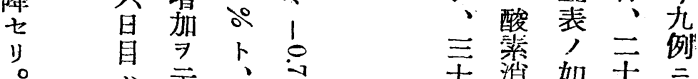

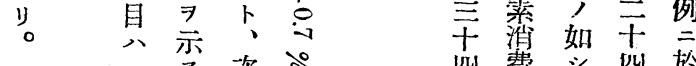

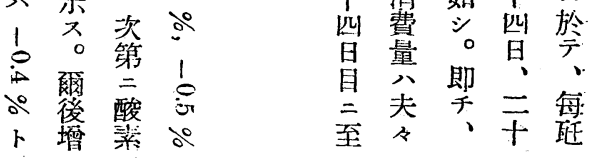




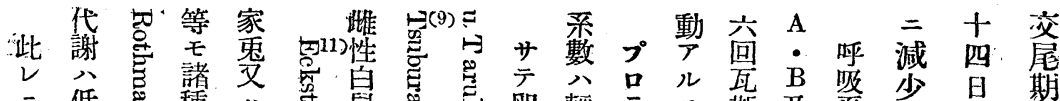

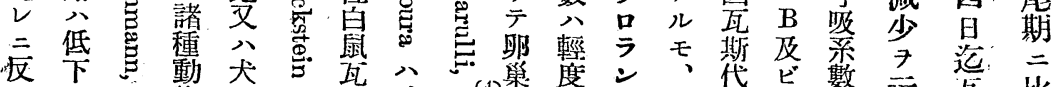

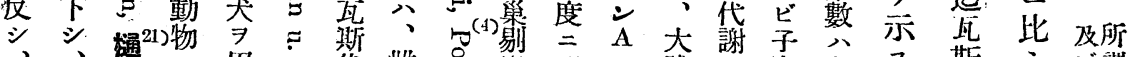

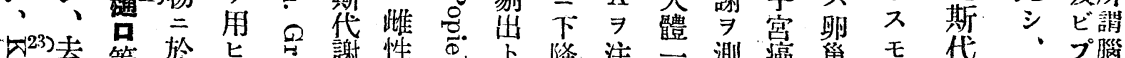

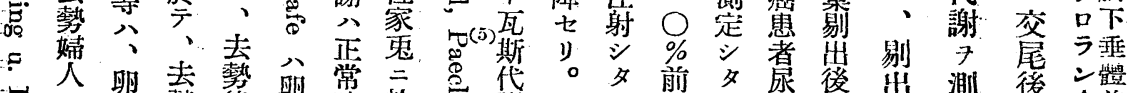

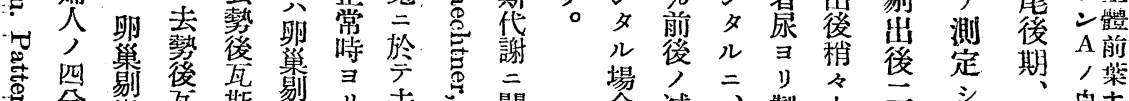

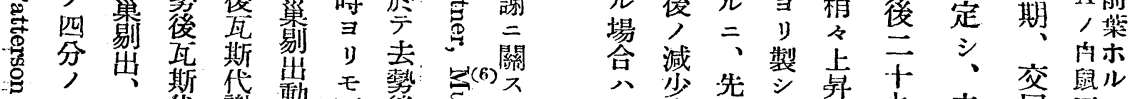

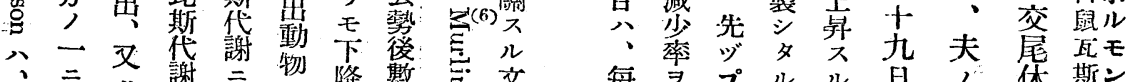

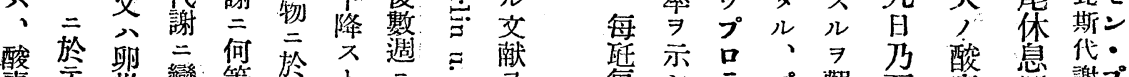

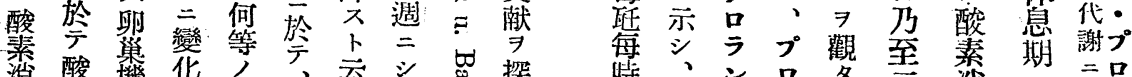

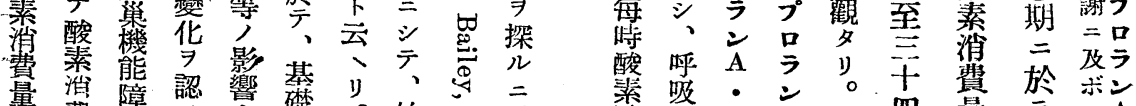
$\Rightarrow$ 費碍

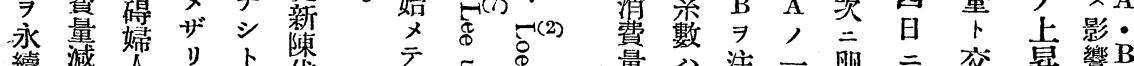

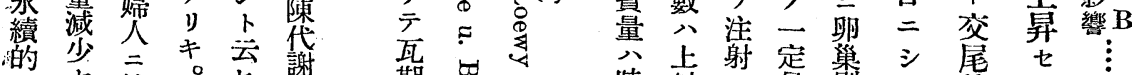

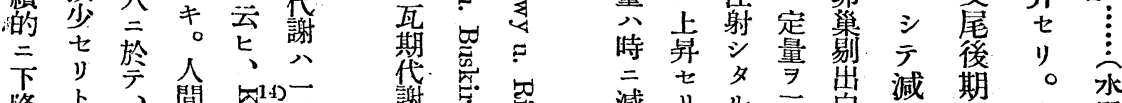

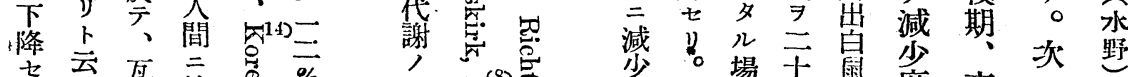

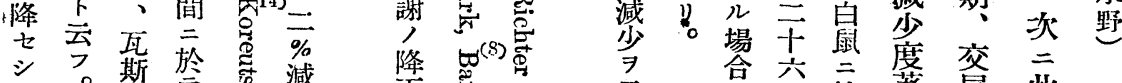

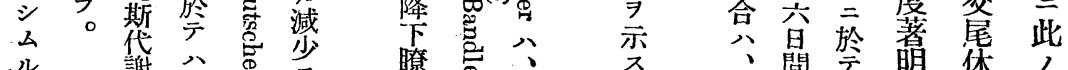

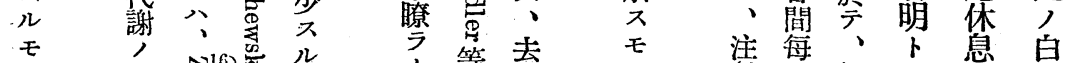

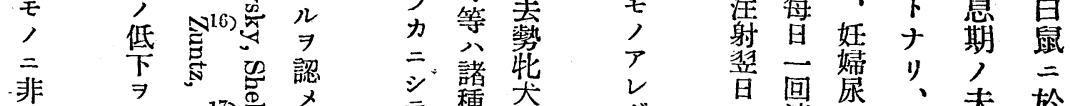

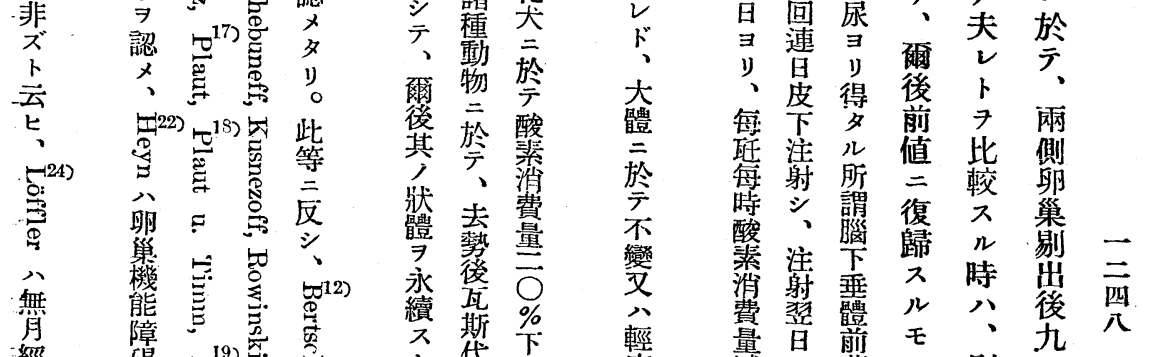

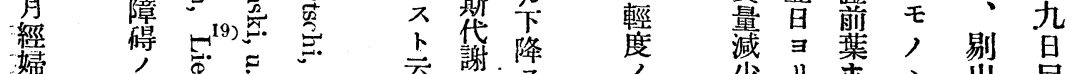

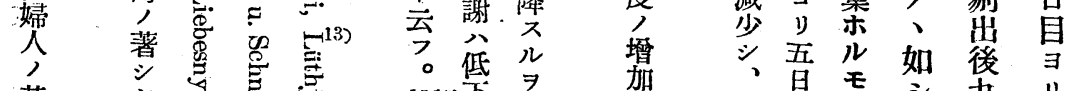

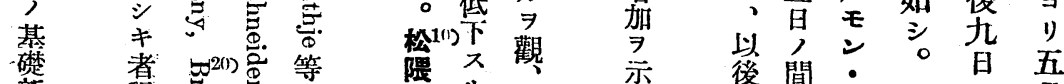

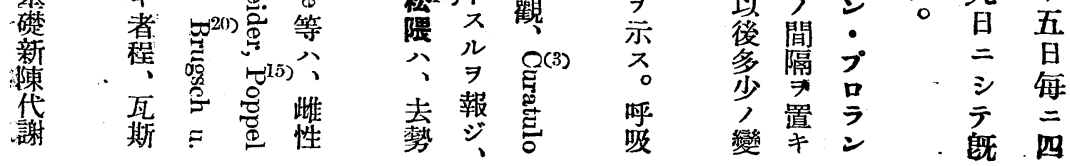




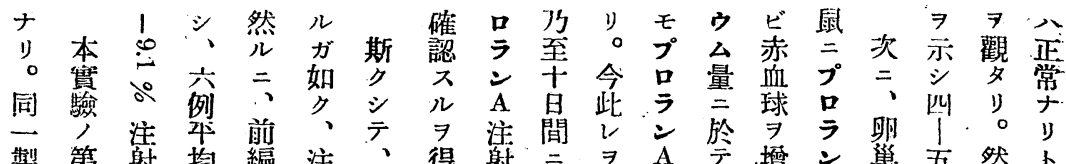

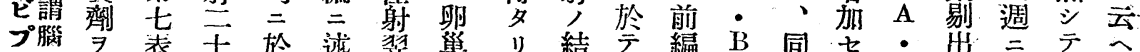

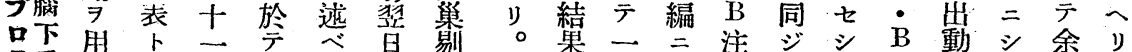

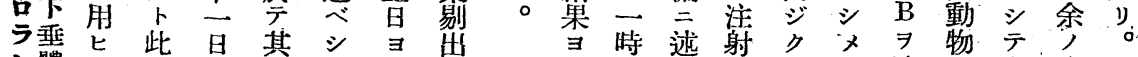

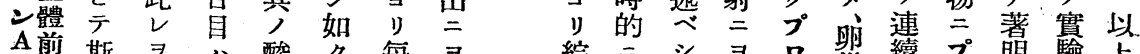

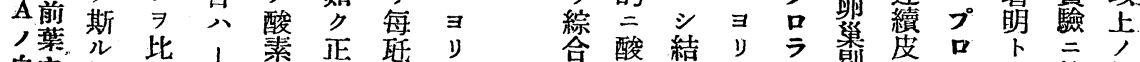
白ホ結 俥

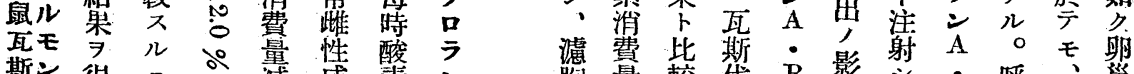

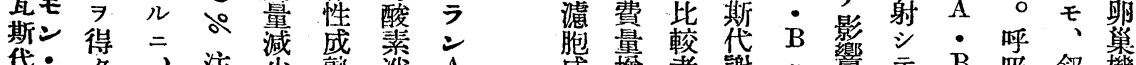

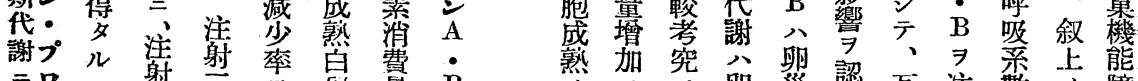

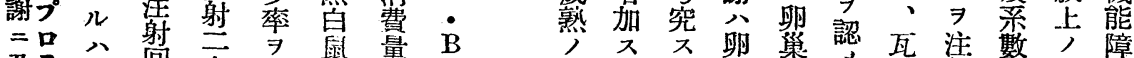

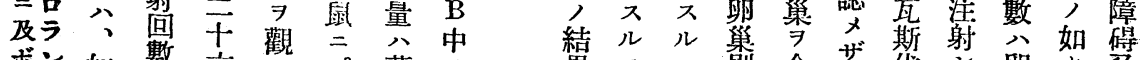

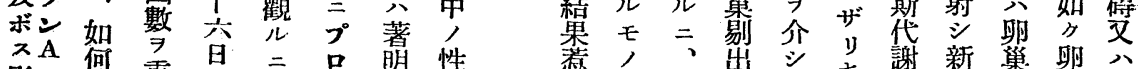

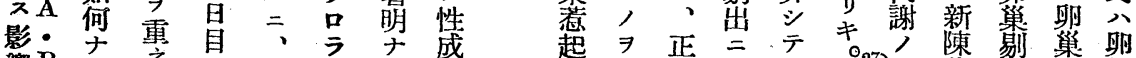

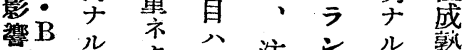
: 原名 $\stackrel{\vdots}{\vdots}$ 泉 特 野 基

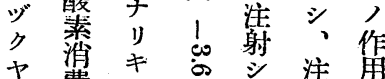
$\Rightarrow$ 費。。集用

考量演ル $\Rightarrow$ 除 究监 㴬場開名

ス率空合始時

二正目注寻宜

前常 公汸录

性 注 宣數交謝

於威。射学貝品

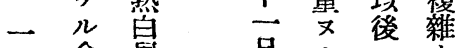

西余鼠 昌几少子

九實於 息從體變

驗 $\begin{aligned} & \text { 足 } \\ & =\end{aligned}$

於減语酸嵄

テ少 さ゚消儿サ

プ攀注費減

口方減率實

シ遥 公少 $\underset{7}{\text { 示 }}$

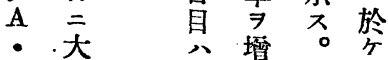

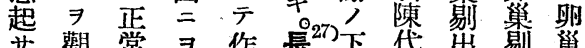

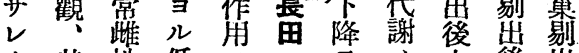

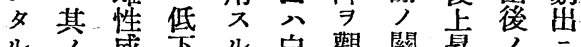

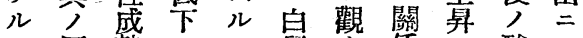

モ原熟 $\exists モ$ 鼠多係不酸

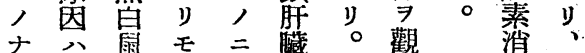

ラ卵三更非多當多費瓦

ン巢於三ズり整ル 量斯

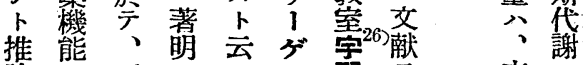

論

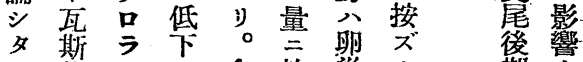

ル 代 謝

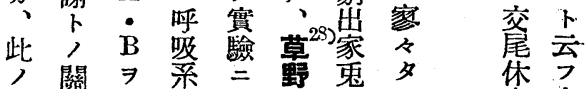

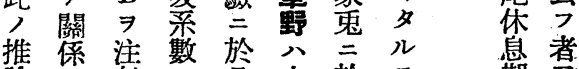

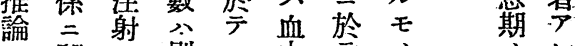

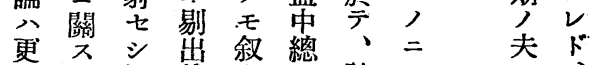

二 場後上热該 $シ$ V

本交合分公注テ、多

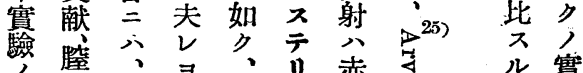

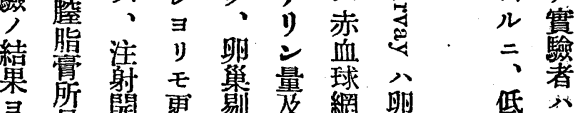

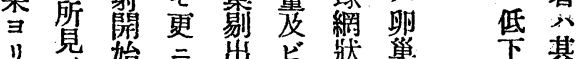

此立後上後力物剔点,

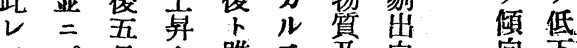




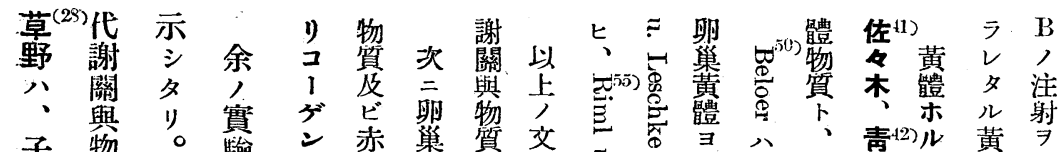

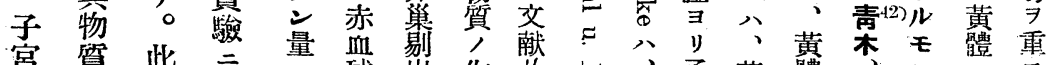

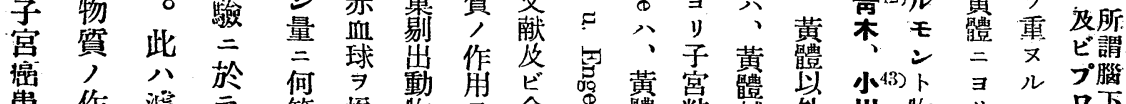

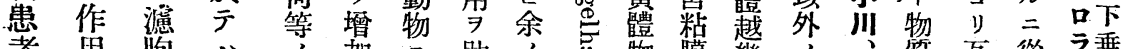

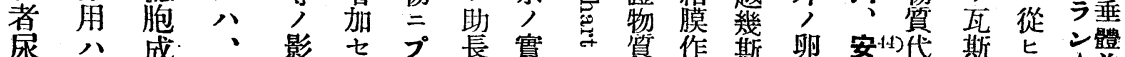

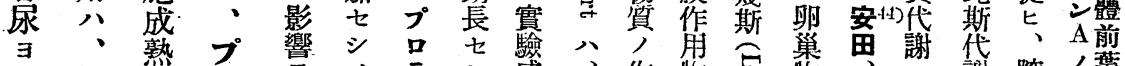

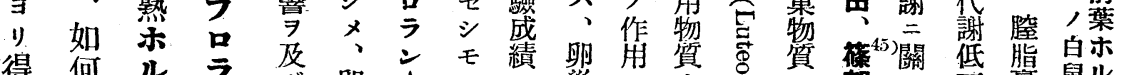

得何ル

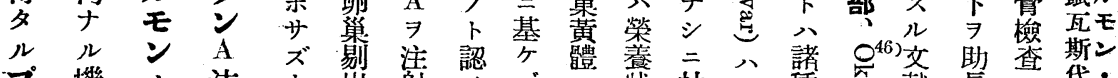

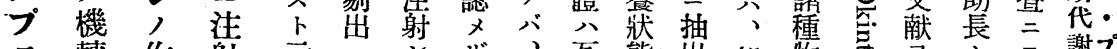

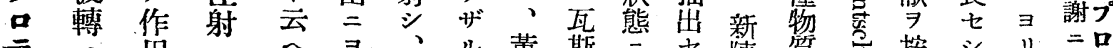

ラ

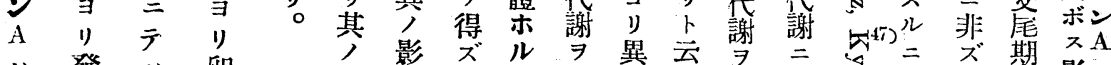

八發八卵作惖 ズ

晓、巢

成 $\pi$ 說 剔

熟儿明仙

雄モ皇

性了得鼠

家ナザ芯

先所贷

血八二謝

中、

總含テ、鑀

乙, 子乍

ス研宮 今

テ究癌桌

俟者七

量 今尿

減 $キ$ 、

少 問 排 呼

七題 泄 吸

シ十七孫

メ ラ 數

血导 、低

中最、午

力近斯,

几當儿傾

手謷新 向

作響

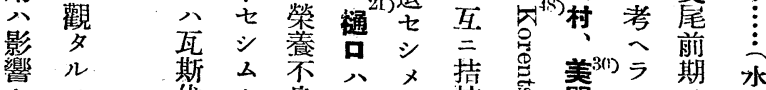

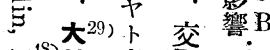

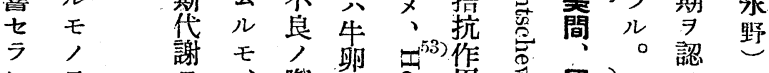

ラ

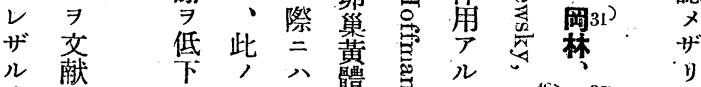

事三 七作瓦體志事 $\mathbb{E}^{4(S)} \#^{32)}$. シ

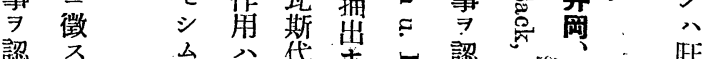

認不公分代永も認

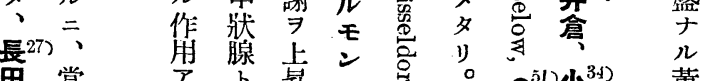

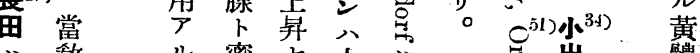

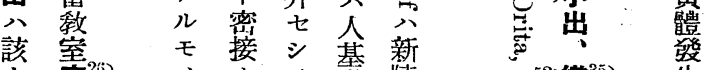

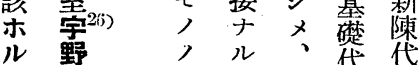

モ 如關可謝謝

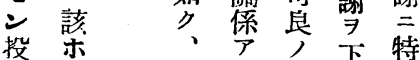

投與ルプリ祭降有

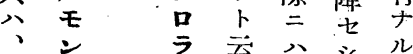

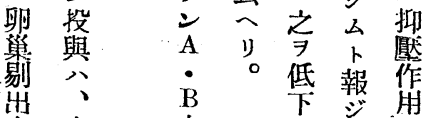

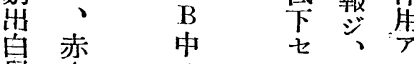

鼠血求新 公 $\overbrace{}^{54)}$

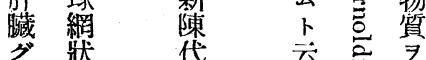

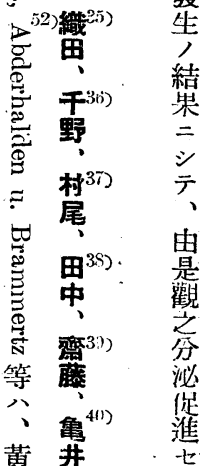




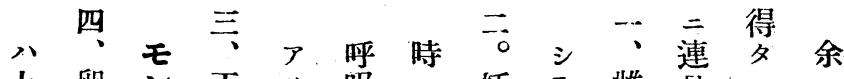

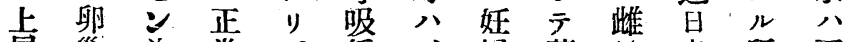

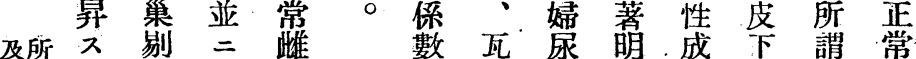

ビ謂ル 出新性公斯 $\exists$ 熟注 腦 雌

プ㡙 7 白陳成代りナ白射下性

口下認鼠代熟 射謝得儿鼠三垂成

垂么二謝白開八分口二テ體熟

體。、關鼠始注ル於、前晢

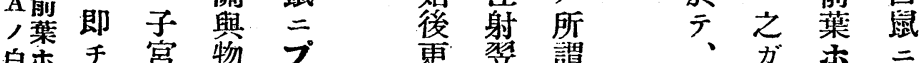

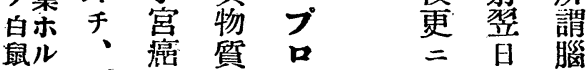

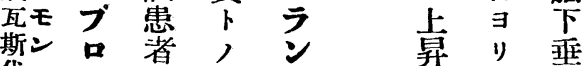

代・泉兩 A

謝プ 浮者

及品 リ, B

ボン中製影

影・六 分響 連

響B 濾儿結 䋶

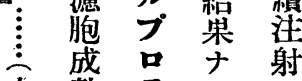

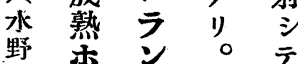

野 栤

モ, 倸

○一酸

, 定素

量 消

ナ゙ 簣

ラ・量

ズ 連

明

眨皮

介 、量

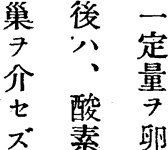

卵西元於

巢 斯 モ テ

入 漖 體

$\circ$ 明 前

即 二 葉

于 低 手

プ 卡

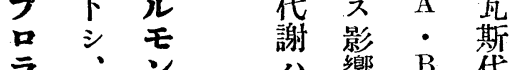

亏 i ?

$\mathrm{A}$ 射 プ

開

中 始 三

二 亲 $\mathrm{A}$

八是.

、目 B

卵稨,

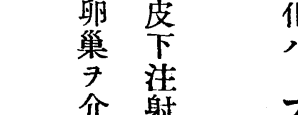

一介 射

垩苋多

五 シ ル

厂

酉斯票

代 度

謝 乍

影

シ 浮 巢

プ 、䨘出

瓦減白

몬

斯 少 鼠

代率二

謝二每

A

$\Rightarrow$ 大

B

低

下儿回

剔代气。

出 謝 プ 性

後 二 邀

瓦及

斯ボント

斯 ホ

低笋 或謝

增

加

七

シ

4

第䇤

章甲

狀

結沓

介

介

ज.

論. 沃

下檢 八及

的

シ查孕 ビ

登

呼、癌 側

吸次患 卵

係, 者巢

數 如 泉 剔

八 $¥$ 出

奌緬製㼛

ス

ル

モ

)

ナ

万得多斯

報

酸多謝

素り。 プ ,

及

㵋。 


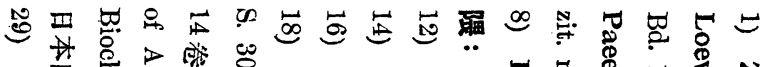

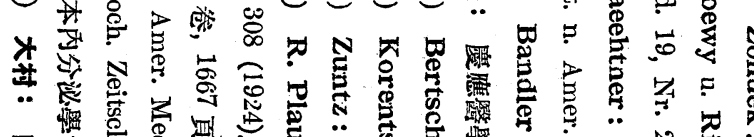

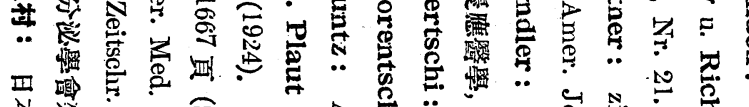

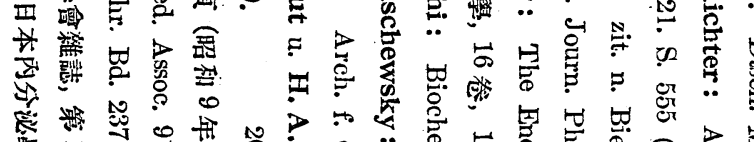

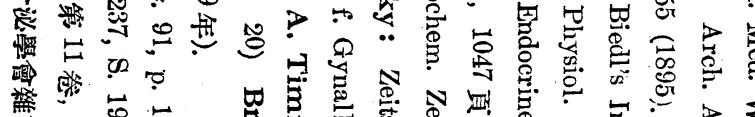

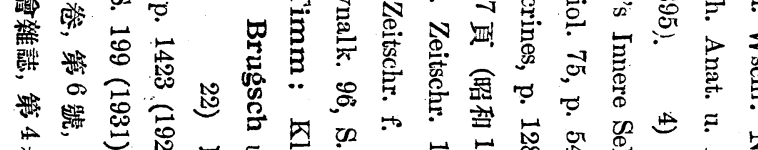

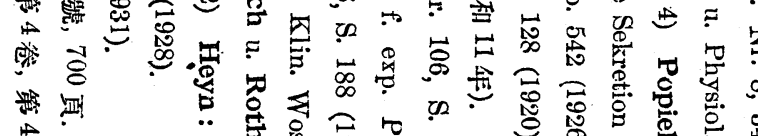

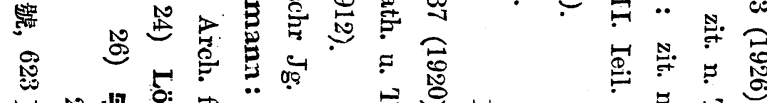

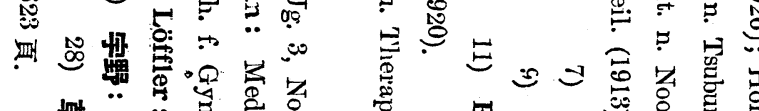

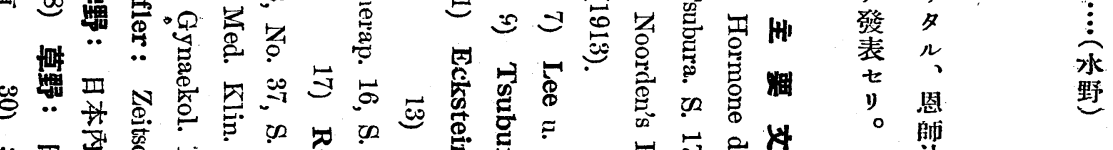

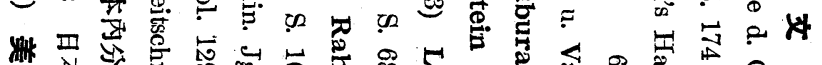

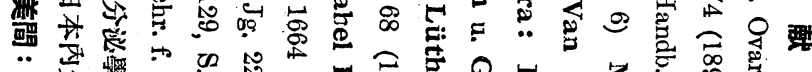

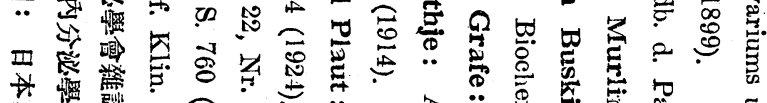

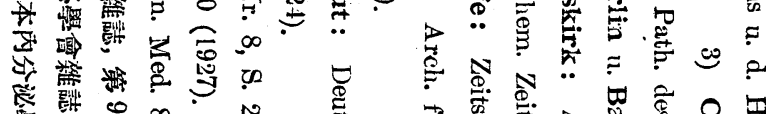

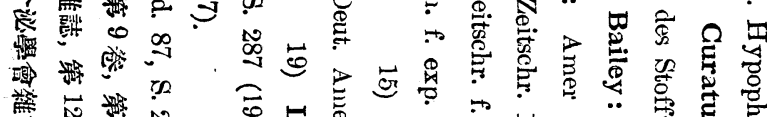

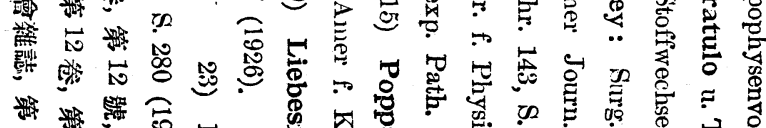

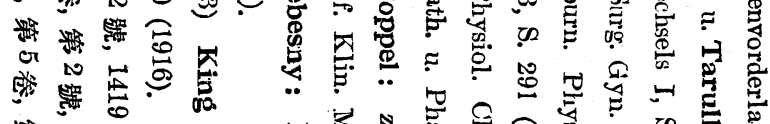

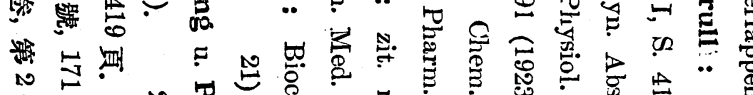

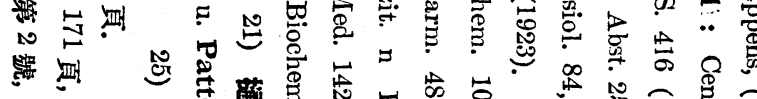

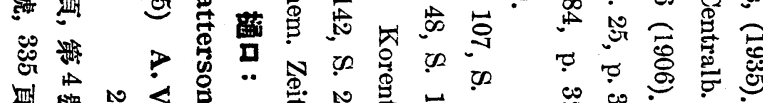
地点

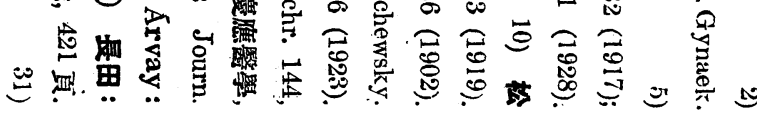

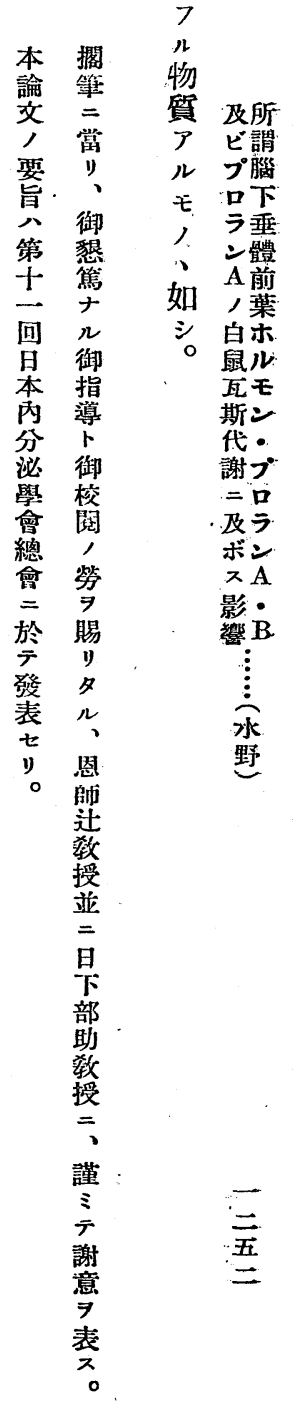




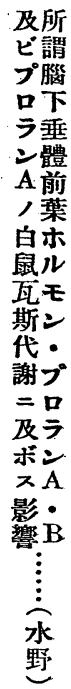

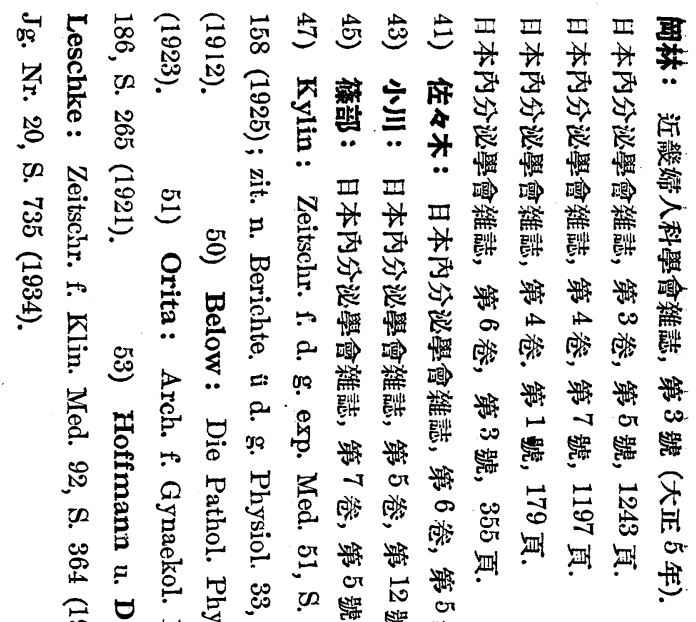

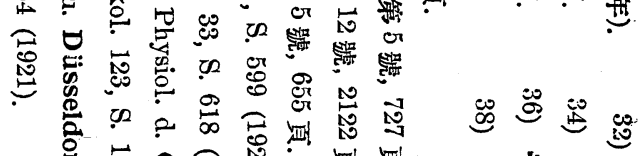

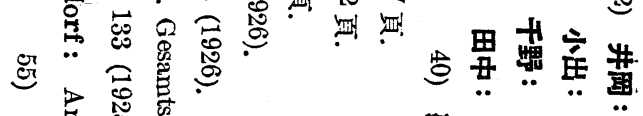

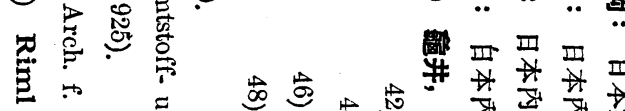

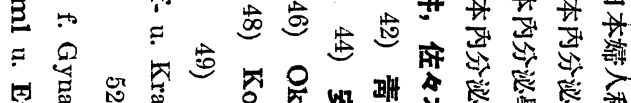

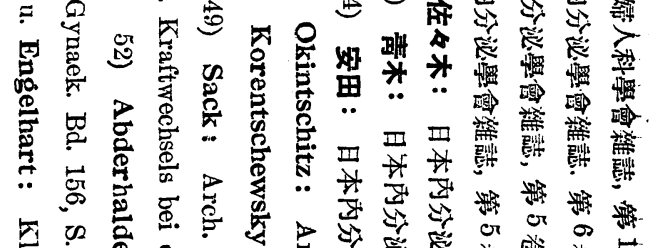

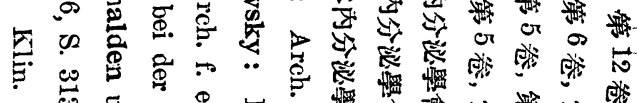

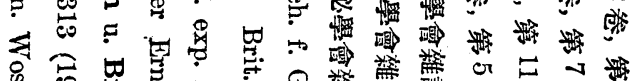

$\underline{\bar{E}}$

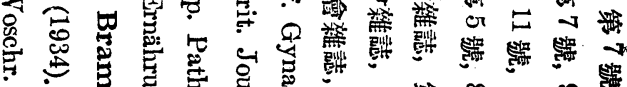

年

: 密要

只芯

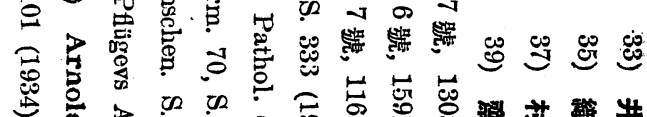

욜 
Behandlung zu vorübergehende Steigerung des $\mathrm{O}_{2}$-Verbrauches, nach dieser Periode aber stets zu deutlicher Abnahme des $\mathrm{O}_{2}$-Verbrauchs bezw. zum Anstiege des R. Q.

3) Bei der Injektion des Prolans A nahm der $\mathrm{O}_{2}$-Verbrauch zu und der R. Q. ab.

(Autoreferat)

\section{Studien über den Einfluss des aus dem Harn einer schwangeren Frau sowie einer Patientin mit Uteruskrebs hergestellten sog. Hypophysenvor- derlappenhormons (Prolan A. B. u. Prolan A) auf den Gaswechsel. \\ II. Mitteilung.}

Versuche an ovariotomierten weiblichen Ratten.

\section{Von}

A. O. Pro. Dr. S. Kusakabe u. Dr. M. Mizuno.

(Aus der I. Med. Klinik der Kaiserl. Univers. zu Kyoto in Japan. Direktor: Prof. Dr. K. Tsuji.)

Der Verhasser studierten den Einfluss der Ovariunsexstirpation auf den Gaswechsel der weissen Ratte indem sie diesen Wechsell vor und nach der Ovariotomie untersuchten. Bei den ovariotomierten Ratten wurde später nach langfortgesetzter Injektion des Prolans A. B. und des Prolans A. Abermals der Gaswechsel bestimmt.. Die Bestimmung des Gaswechsels erfolgte nach derselben Methode wie bei der ersten Arbeit.

Die Resultate sind die folgenden:

1) Die Ovariotomie führte bei erwashsenen weissen Ratten zur Abnahme des $\mathrm{O}_{2}$-Verbrauch und zum Anstieg des respiratorischen Koeffizienten (als R. Q. bezeichnet). Die Abnahme des $\mathrm{O}_{2}$-Verbrauchs erreichte ihren höchsten Punkt einige Wochen nach der Ovariotomie. 
2) Bei den ovariotomierten Ratten kam es durch fortgesetzte tägliche Injektion des Prolans A. B. gleich vom 1. Tag nach der Injektion an zur Herabsetzung des $\mathrm{O}_{-}$-Verbrauchs und zum Anstieg des R.Q.. Daraus war zu schliessen, dass das Prolan A. B. eine wirsame Substanz enthält, für deren Wirkung es keiner Vermittlung des Ovariums bedarf.

3) Aus der I. u. II. Mitteilung geht folgendes hervor:

Die den Gaswechsel der weissen Ratten beeinflussende Wirkung des Prolans A. B. heruht auf dem in diesem enthaltenen Sexualreifhormon und Stoffwechselstoff.

4) Die mit fortgesetzter Prolan A-injektion behandelten ovariotomierten Ratten zeigten Zunahme des $\mathrm{O}_{2}$-Verbrauchs.

Das Pṛolan A enthält also neben dem Follikelreifungshormon eine gewisse gaswechselbeeinflussende Substanz für deren Wirkung es keiner Vermittlung des Ovariums bedarf.

(Autoreferat) 